\title{
Building Applications, Opportunities and Challenges of Active Shading Systems: A State-Of-The-Art Review
}

\author{
Joud Al Dakheel and Kheira Tabet Aoul * \\ Architectural Engineering Department, United Arab Emirates University, P.O. Box 15551 Al Ain, UAE; \\ 200935298@uaeu.ac.ae \\ * Correspondence: kheira.anissa@uaeu.ac.ae; Tel.: +971-566-433-648
}

Academic Editor: Arman Hashemi

Received: 28 June 2017; Accepted: 4 August 2017; Published: 23 October 2017

\begin{abstract}
Active shading systems in buildings have emerged as a high performing shading solution that selectively and optimally controls daylight and heat gains. Active shading systems are increasingly used in buildings, due to their ability to mainly improve the building environment, reduce energy consumption and in some cases generate energy. They may be categorized into three classes: smart glazing, kinetic shading and integrated renewable energy shading. This paper reviews the current status of the different types in terms of design principle and working mechanism of the systems, performance, control strategies and building applications. Challenges, limitations and future opportunities of the systems are then discussed. The review highlights that despite its high initial cost, the electrochromic (EC) glazing is the most applied smart glazing due to the extensive use of glass in buildings under all climatic conditions. In terms of external shadings, the rotating shading type is the predominantly used one in buildings due to its low initial cost. Algae façades and folding shading systems are still emerging types, with high initial and maintenance costs and requiring specialist installers. The algae façade systems and PV integrated shading systems are a promising solution due to their dual benefits of providing shading and generating electricity. Active shading systems were found to save 12 to $50 \%$ of the building cooling electricity consumption.
\end{abstract}

Keywords: active shading systems; kinetic shading devices; smart glazing; rotating shading systems; folding shading systems; photovoltaic (PV); solar collector; algae façade system; controls

\section{Introduction}

Daylighting in buildings provides multidimensional benefits that have been widely reviewed in the specialized literature [1]. The provision of daylight through building openings permits views to the outdoors [2], which concurrently contributes to visual [3], psychological comforts [4], health [5], and productivity [6]. Additionally, optimum daylighting design strategies reduce reliance on artificial lighting and lessen energy consumption $[7,8]$. Although daylighting has many benefits, it has however undesirable side effects such as heat gain and glare [9]. Therefore, successful daylighting designs will consider the use of shading devices to reduce glare and excess heat gain in buildings [10]. Shading devices are used in buildings to provide a healthy balance by reducing the excessive glare and heat gain and providing privacy [11].

\subsection{Passive versus Active Shading Systems in Buildings}

Fixed shading devices are a prominent feature in vernacular architecture. They are often designed in response to environmental conditions using locally available materials such as clay, tree branches, concrete, wood planks, bamboo and others to shade the buildings from direct sunlight [12-15]. The modern architectural movement dismissed these strategies until the 1970 
energy crisis, which triggered a renewed interest in passive design strategies as well as pressing for advanced solutions [16].

Conventional static passive shading devices are often categorized first as internal or external based on location of the system [11]. The performance of shading devices including overhangs [17], external roller shades [18], Venetian blinds [19] and internal shadings [20] were investigated in several studies. Furthermore, fixed external shading devices have been widely known as an effective way of controlling heat gain and glare in buildings and reducing cooling energy and cost reductions in different climatic conditions [21-23]. By comparison, external shading devices are more effective than internal shading devices since they are more efficient in decreasing the cooling loads of buildings in hot climate regions [11]. Fixed shading devices have, however, their limitations, the most important of which is their inability to adapt to the external conditions variations as well as blocking the view to the outside [24].

At the other end of the spectrum, active shading strategies try to achieve a balance between sufficient daylighting levels, providing solar protection, energy balance and enabling the occupants with the flexibility to control the shading devices according to their evolving needs [25]. Active shading devices are systems that tend to change their properties in response to exterior climate and interior requirements [26]. The use of active shading systems decreases the undesirable solar heat gain, increase daylight, provide control for the users, may generate on-site energy and increase the use of natural ventilation $[25,27,28]$. The active systems can be within the glazing of the openings or as an exterior shading system. This is usually achieved through the use of smart glazing technologies [29-31], sensors and control systems [32,33], or through the application of smart dynamic shading devices [34,35].

\subsection{Aim of the Review Paper and Objective}

The main objective of this paper is to establish the extent of knowledge acquired on the subject through a review of the different emerging types of active shading systems and their applications in buildings. The three major types of active shading systems are reviewed; smart glazing systems, automated active (or kinetic) shading systems and shading systems that incorporate renewable energy. The types of control systems and mechanism used in active shading systems were then reviewed, as they are different and have implications on performance. Finally, the review assesses their potential, limitations and opportunities for further development and improvement.

The search process consisted of identifying studies with a search strategy across Science-Direct database and Google Scholar. The initial search keywords used were active shading systems, smart glazing, kinetic shading systems, integrated renewable energy and shading systems and it yielded more than 500 papers. However, the papers that were eligible after pre-selection focused on electrochromic (EC) glazing, suspended particle devices (SPDs), liquid crystal devices (LCDs), rotating shading systems, folding shading systems, PV integrated shading systems, algae façade systems and solar collector integrated shading systems. Further focused search considered the types of shading systems along the following related keywords; design principles, types, working mechanism, performances and application in buildings and resulted in a 165 direct relevant papers investigated in this review.

\section{Active Shading Systems}

Active or responsive shading systems, also called dynamic or kinetic shading systems, are often designed to respond to one or multiple environmental situations including: daylighting control [36], solar thermal control, ventilation control, and in addition sometimes energy generation $[37,38]$.

The application of active shading systems is an important step towards improving the energy efficiency in the built environment [39]. By using active shading systems, buildings tend to adapt to evolving external conditions $[39,40]$. These systems can allow or block solar radiation access into the interior space by adjusting a device installed either inside or on the building skin. 
Active shading systems can be classified into three main categories: the first one comprises: (i) the glazing in the form of smart glazing or as (ii) kinetic external shading devices or as (iii) shading devices that incorporate renewable energy generation. These main systems are the target of this review. First, smart glazing devices include suspended particle devices (SPDs), electrochromic (EC) devices and liquid crystal devices (LCDs). The second type of active shading is the kinetic external shading systems. This review considers mechanically movable dynamic shading systems which include the rotating and folding shading systems. The third type is the integrated renewable energy shading systems. The integration of renewable energy can be achieved by using photovoltaic panels (PV) attached on shading devices [41], or by using algae façade systems which can generate electricity [42], or through solar collectors attached on shading systems [43]. The active shading systems types reviewed in this study are shown in Figure 1.

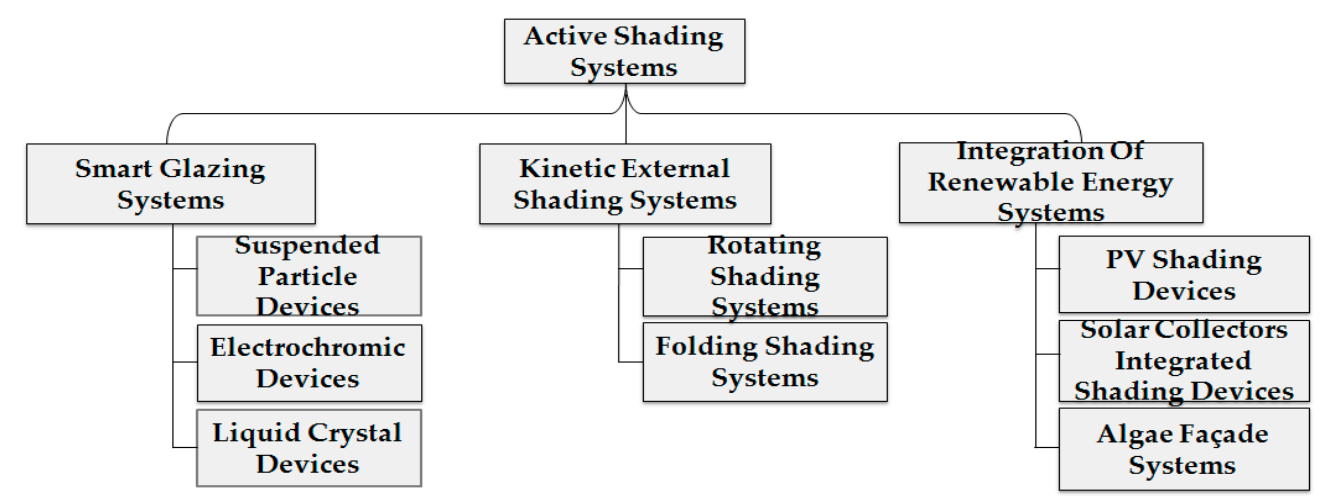

Figure 1. Active shading systems classification diagram.

\subsection{Smart Glazing Systems}

Windows with dynamic optical properties are a form of building shade. Smart glass, often called smart windows, is defined to be the glass whose light transmission properties are altered when voltage, light or heat is applied, by changing from translucent to transparent [44].

The function of a smart window is to control the transmission of light into and out of the glazing system, according to occupants' comfort. Smart windows can also regulate lighting and heating levels for energy load management. Smart glass technologies include SPDs, EC devices and LCDs [45]. Installing smart glass in buildings' envelope, is similar to creating climate adaptable building shells, in which costs for heating, cooling and lighting are reduced [46,47]. Additionally, smart glass prevents $99.4 \%$ of ultraviolet light, which reduces furniture and curtain fabric fading [44,45]. The three systems require transparent conductors as electrical contacts.

SPDs tend to rapidly switch from a dark bluish-black state to a clear greyish appearance when voltage is applied to control the amount of light, glare and heat passing through [48].

The EC devices use a technology that utilizes an electrical voltage to control the amount of light passing through the glass [49]. ECs offer dynamic and responsive control that responds to the external changing conditions and controls visible transmittance, reduce glare and improve indoor light environment when compared to regular and low-E glass. Additionally, when compared to the fixed shading devices, they offer a dynamic solar radiation and do not block the view $[49,50]$.

LCDs use liquid crystals that dissolve into a liquid polymer they will, in turn, solidify. The liquid crystals are randomly arranged in the droplets, resulting in scattering of light as it passes through the smart window assembly and forming a translucent film [51].

The performance of smart glazing is first evaluated through the transmittance modulation range in the visible and whole solar spectrum. Secondly, the expected lifetime and number of achieved cycles is considered. Finally, its size as the larger the devices, the longer the switching time for coloration and 
bleaching of the glass [45]. Smart glazing acts differently during the transparent and opaque phases to control the transmitted solar radiation.

The design principle, types, working mechanism, diagrams, special features and benefits of the three types of smart glazing are summarized in Table 1.

The performance of smart glazing devices is indicated by several factors, such as the electrical, optical and thermal properties that depend on the structural composition and configuration of the EC device itself. Typically, the required performance parameters include the specification of: (1) switching speed; (2) switching voltage; (3) optical reflectance; (4) color rendering; (5) solar heat gain coefficient; (6) optical memory coefficients; (7) thermal transmittance; (8) optical transmittance coefficients; (9) lifetime and (10) operating temperature [44,52]. The performance of the three types of smart glazing systems is summarized in Table 2 according to the climatic conditions while highlighting the main variables addressed in the studies. 
Table 1. Summary of smart glazing types.

\begin{tabular}{|c|c|c|c|}
\hline System & Electrochromic Glazing (EC) & Suspended Particle Devices (SPDs) & Liquid Crystal Devices (LCDs) \\
\hline $\begin{array}{c}\text { Design } \\
\text { Principle }\end{array}$ & $\begin{array}{l}\text { EC glazing is } 1 \mu \mathrm{m} \text { thick of purely ionic } \\
\text { conductor placed between electrochromic } \\
\text { and counter electrode layers that are placed } \\
\text { between transparent electrical conductor } \\
\text { layers [53]. } \\
\text { - Change optical properties by switching } \\
\text { between their oxidized and reduced } \\
\text { forms [45]. }\end{array}$ & $\begin{array}{l}\text { - SPDs consist of 3-5 layers by which the } \\
\text { active layer contains needle-shaped dipolar } \\
\text { particles of polyiodides [54]. } \\
\text { Particles are less than } 1 \mu \mathrm{m} \text { in linear size [55]. } \\
\text { - The size of the particles is usually less than } \\
200 \mathrm{~nm} \text { to minimize light scattering and } \\
\text { avoid non-desired haze [48]. }\end{array}$ & $\begin{array}{l}\text { - LCD consist of liquid crystal material } \\
\text { positioned between two sheets of glass [56]. } \\
\text { LCD has field sequential color displays that } \\
\text { uses red (R), green (G), and blue (B) light } \\
\text { emitting diodes (LEDs) without noticeable } \\
\text { color breakup [57]. }\end{array}$ \\
\hline $\begin{array}{l}\text { Types and } \\
\text { Materials }\end{array}$ & $\begin{array}{ll} & \text { Conventional Electrochromic (CEC) } \\
\text { glazing [58]. } \\
\text { - NIR switching electrochromic (NEC) } \\
\text { glazing [59]. } \\
\text { "Dual-band" electrochromic (DBEC) [60]. }\end{array}$ & - $\quad$ Evacuated vacuum SPD [61]. & $\begin{array}{ll}\text { - } & \text { Polymer-stabilized blue phase (PSBP) [62]. } \\
\text { - } & \text { Polymer-dispersed LC (PDLC) reported [63]. } \\
\text { - } & \text { Liquid crystal on silicon (LCoS) displays [64]. } \\
\text { - } & \text { Optically isotropic LC (OILC) [62]. } \\
\text { - } & \text { Gel dispersed liquid crystals (GDLC). }\end{array}$ \\
\hline $\begin{array}{l}\text { Working } \\
\text { Mechanism }\end{array}$ & $\begin{array}{l}\text { EC glazing has a visible light transmission of } \\
62 \% \text { and allows } 47 \% \text { of the incident solar } \\
\text { energy to the building interior in the clear } \\
\text { state [52]. } \\
\text { Amount of incident solar energy going } \\
\text { inside the building is reduced by } 81 \% \text { when } \\
\text { a low DC voltage is applied [65]. } \\
\text { - Solar irradiation is absorbed when the films } \\
\text { are tinted. } \\
\text { Thermal energy is re-radiated based on the } \\
\text { emissivity's of the films and the glass [65]. }\end{array}$ & $\begin{array}{l}\text { - During the "off" state, the SPDs are } \\
\text { randomly oriented and absorb/scatter } \\
\text { visible light [48]. } \\
\text { - Then SPD shows a bluish-black dark color. } \\
\text { - The scattering effect is due to the particles } \\
\text { and is most prominent at short wavelengths. } \\
\text { - During the "on" state the electric field is } \\
\text { applied and the particles line up } \\
\text { perpendicularly to the substrates. } \\
\text { Then, more light is allowed to pass through } \\
\text { to increase the transmission [48]. }\end{array}$ & $\begin{array}{l}\text { - Liquid crystal molecules are aligned in } \\
\text { parallel with the glass surface [56]. } \\
\text { When voltage is applied, the direction is } \\
\text { changed and they become vertical to the } \\
\text { glass surface. } \\
\text { Then light passes through the droplets with } \\
\text { very little scattering and resulting in a } \\
\text { transparent state. } \\
\text { The quantity of light transmission can be } \\
\text { controlled by combining the motion of liquid } \\
\text { crystal molecules and the direction of } \\
\text { polarization of two polarizing plates } \\
\text { attached to the both outer sides of the glass } \\
\text { sheets [56]. }\end{array}$ \\
\hline
\end{tabular}


Table 1. Cont

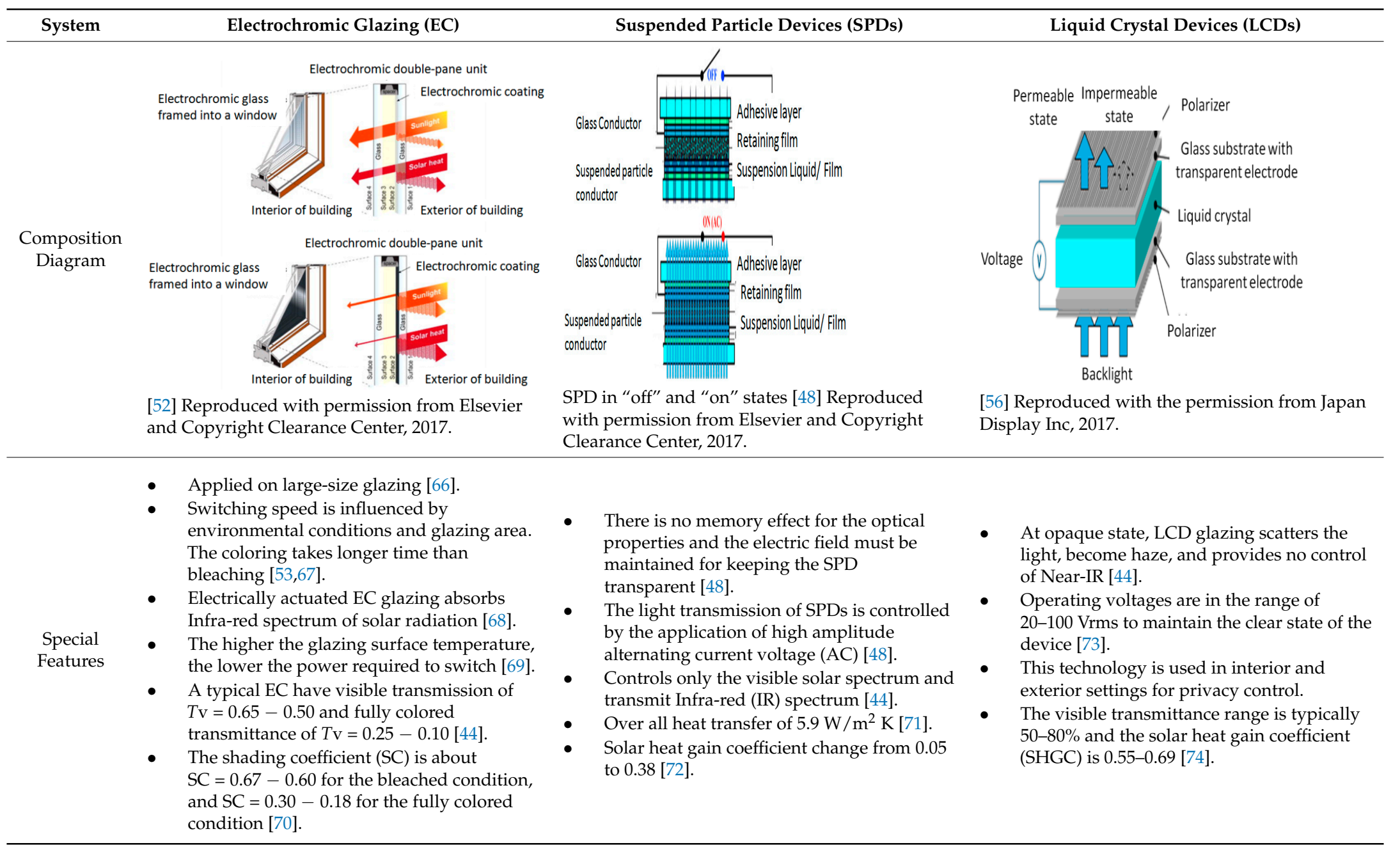


Table 1. Cont.

\begin{tabular}{|c|c|c|c|}
\hline System & Electrochromic Glazing (EC) & Suspended Particle Devices (SPDs) & Liquid Crystal Devices (LCDs) \\
\hline Benefits & $\begin{array}{l}\text { Requires power only during switching, } \\
\text { where they consume a low voltage to switch } \\
\text { usually } 1-5 \mathrm{~V} \text {. } \\
\text { Constant dimming and most designs have } \\
\text { long-term memory usually } 12-48 \mathrm{~h} \text { [44,53]. } \\
\text { Has a low energy consumption, usually } \\
8 \mathrm{~W} / \mathrm{m}^{2} \text {, and becomes almost zero when } \\
\text { they are kept at constant conditions, due to } \\
\text { their considerable open circuit memory [75]. } \\
\text { Coloration phases are virtually infinite and } \\
\text { are capable of blocking both direct and } \\
\text { diffuse solar radiation [52]. Improves the } \\
\text { daylighting of buildings and offices, which } \\
\text { leads to significant cost savings and improve } \\
\text { labor productivity [50]. }\end{array}$ & $\begin{array}{l}\text { - SPD glazing is the most suitable among other } \\
\text { types of glazing for building application. } \\
\text { Can connect directly with AC main power } \\
\text { supply without the need for conversion } \\
\text { system (EC glazing requires an AC to DC } \\
\text { inverter to connect with mains) [76]. } \\
\text { - Controls solar heat gain due to its variable } \\
\text { transparency [72]. } \\
\text { - Facilitates switchable single or double } \\
\text { glazing systems [71]. } \\
\text { Optical response times are around 1-3 s, } \\
\text { which is the same range as for LCD devices } \\
\text { and less than EC devices [48]. }\end{array}$ & $\begin{array}{l}\text { - Recent advances in next-generation LCDs } \\
\text { with a fast response time [77]. } \\
\text { OILC use makes wide viewing angle without } \\
\text { an alignment layer [77]. Optical response } \\
\text { times are around 1-3 s, which is less than EC } \\
\text { devices [48]. }\end{array}$ \\
\hline
\end{tabular}


Table 2. Performance of smart glazing types according to climatic conditions.

\begin{tabular}{|c|c|c|c|}
\hline Parameters & Performance of EC & Performance of SPDs & Performance of LCDs \\
\hline $\begin{array}{c}\text { Variable } \\
\text { addressed }\end{array}$ & - $\quad$ Energy saving & $\begin{array}{ll}\text { - } & \text { U-Value } \\
& \text { Switching Power }\end{array}$ & $\begin{array}{ll}\text { - } & \text { Response time } \\
\text { - } & \text { Material and optical transmittance } \\
\text { Haze coefficient }\end{array}$ \\
\hline $\begin{array}{l}\text { Cold climatic } \\
\text { conditions }\end{array}$ & $\begin{array}{l}\text { - Large-size EC windows facing south-east, } \\
\text { used in a building in Oakland, California } \\
\text { during winter was tested and the result } \\
\text { showed that on a clear winter day, the } \\
\text { average window luminance exceeded } 850 \\
\mathrm{~cd} / \mathrm{m}^{2} \text { and the lighting energy was } \\
\text { reduced by } 6-24 \% \text { in the } 11 \% \text { glazing, } \\
\text { while the energy was } 3 \% \text { reduced when } \\
13 \% \text { glazing was used [53]. }\end{array}$ & $\begin{array}{l}\text { - Using a thermally insulated test cell yielded a U-value } \\
\text { of } 5.9 \mathrm{~W} / \mathrm{m}^{2} \mathrm{~K} \text { in cold climate in Ireland [71]. While the } \\
\text { use of low heat loss switchable SPD glazing offered a } \\
\text { low overall U-value, which varied between } 1.00 \text { and } \\
1.16 \mathrm{~W} / \mathrm{m}^{2} \mathrm{~K} \text { in Ireland [61]. } \\
\text { Gosh et al. (2016) also tested the potential of powering } \\
\text { SPD glazing from photovoltaic device and found that } \\
\text { for a } 1 \mathrm{~m}^{2} \text { of SPD glass under cold climatic conditions in } \\
\text { Dublin the switching power consumption is } 10.42 \mathrm{kWh} \\
\text { which can be supplied by } 1 \mathrm{~W} \text { PV. Thus, there is a } \\
\text { potential combination for SPD and PV for future low } \\
\text { building annual energy consumption [76]. A } 40 \mathrm{Wp} P V \\
\text { device continuously powered a 0.07 W SPD glazing. } \\
\text { Low sizing ratio of } 1.12 \text { between PV and inverter } \\
\text { offered less power losses from inverter output [76]. }\end{array}$ & $\begin{array}{l}\text { - Glass gel-dispersed liquid crystal (GDLC) which has } \\
\text { high quality electro-optical behavior was investigated in } \\
\text { order to overcome the limitations of regular PDLC at } \\
\text { cold climate in South Korea and showed a fast response } \\
\text { time of } ~ 0.5 \text { and } 3 \text { ms which is } 10 \text { times shorter than that } \\
\text { of PDLC, respectively for the on and off processes, high } \\
\text { contrast and low haziness [78]. } \\
\text { The use of films of silver nanowires was investigated by } \\
\text { Khaligh et al. (2015) in Ontario, Canada as an alternate } \\
\text { electrode material to the PDLC [79]. It was found that } \\
\text { the material and fabrication costs of silver nanowire } \\
\text { films are lower than ITO and enable transparency of } \\
\Delta \text { Ton - off }=57 \% \text { versus } \Delta \text { Ton }- \text { off }=46 \% \text { for the } \\
\text { ITO-based devices and a lower voltage supply [79]. } \\
\text { A } 20 \mu \text { mm commercial PDLC layer has been developed in } \\
\text { South Korea between ITO coated polyester films to } \\
\text { achieve a device with haze coefficient changing from } \\
0.09 \text { to } 0.90 \text {. The device exhibits good temperature } \\
\text { stability between } 0 \text { and } 60^{\circ} \mathrm{C}[80] \text {. }\end{array}$ \\
\hline $\begin{array}{l}\text { Variable } \\
\text { addressed }\end{array}$ & - Power and energy consumption & $\begin{array}{l}\text { - U-values and SHGC } \\
\text { - Transmittance reflectance, color appearance and haze. }\end{array}$ & - $\quad$ Light transmittance \\
\hline $\begin{array}{l}\text { Warm and hot } \\
\text { climatic } \\
\text { conditions }\end{array}$ & $\begin{array}{l}\text { - EC devices can lead to a } 30 \% \text { reduction in } \\
\text { the annual power consumption and in } \\
\text { peak demand by } 23 \% \text { in large area } \\
\text { buildings in hot climatic conditions [81]. } \\
\text { Up to } 50 \% \text { of the primary energy } \\
\text { consumed in air-conditioning is saved by } \\
\text { the use of EC windows [82]. }\end{array}$ & $\begin{array}{l}\text { - It was claimed by Gosh et al. (2016) that high U-values } \\
\text { and variable SHGC makes the SPD glazing to be } \\
\text { suitable for summer. } \\
\text { (SHGC) varied between } 0.05 \text { (when opaque) and } 0.38 \\
\text { (when transparent) and U-value varied between } \\
5.02 \mathrm{~W} / \mathrm{m}^{2} \mathrm{~K} \text { and } 5.2 \mathrm{~W} / \mathrm{m}^{2} \mathrm{~K} \text { for the two states and } \\
\text { showed } 6 \mathrm{~kW} \text { h cooling load reduction [72]. } \\
\text { Total and diffuse components of transmittance and } \\
\text { reflectance, along with color appearance and haze were } \\
\text { used in model calculations to predict the thickness of } \\
\text { the active layer during summer period and showed } \\
\text { thicknesses of } 200-300 \mu \mathrm{m} \text { as most optimum for } \\
\text { SPD-based smart window applications [48]. }\end{array}$ & $\begin{array}{l}\text { - The light-controlled transmittance in a } \\
\text { polymer-dispersed liquid crystals (PDLC) device was } \\
\text { investigated by Cupelli et al. (2009) during warm } \\
\text { climate in Calabria, Italy. It was claimed to self-increase } \\
\text { scattering as a function of the light intensity and } \\
\text { self-control the incident daylight and glare as a function } \\
\text { of incident intensity both in building and automotive } \\
\text { applications [83]. }\end{array}$ \\
\hline
\end{tabular}


Table 2. Cont

\begin{tabular}{|c|c|c|c|}
\hline Parameters & Performance of EC & Performance of SPDs & Performance of LCDs \\
\hline $\begin{array}{c}\text { Variable } \\
\text { addressed }\end{array}$ & $\begin{array}{ll}\text { - } & \text { Energy consumption } \\
\text { - } & \text { Energy savings }\end{array}$ & - & - \\
\hline $\begin{array}{l}\text { Mixed climatic } \\
\text { conditions }\end{array}$ & $\begin{array}{l}\text { - The energy consumption of EC windows } \\
\text { was tested in cold and hot climates in two } \\
\text { prototype buildings in Chicago and } \\
\text { Houston. The results suggested that the } \\
\text { annual peak electric demand was reduced } \\
\text { by } 7-8 \% \text { for moderate-area windows and } \\
\text { by } 14-16 \% \text { for large-area windows in } \\
\text { either climates [46]. } \\
\text { The performance of near-infrared } \\
\text { switching electrochromic (NEC) window } \\
\text { glazing was tested, using the COMFEN } \\
\text { software to simulate a broad range of } \\
\text { NEC performance levels, for commercial } \\
\text { and residential buildings in } 16 \text { climatic } \\
\text { variations-representative reference cities. } \\
\text { The results showed an annual HVAC } \\
\text { energy savings up to } 11.6 \% \text { with potential } \\
\text { as high as } 11 \mathrm{kWh} / \mathrm{m}^{2} \text { per year for } \\
\text { commercial buildings, and up to } 13 \% \text { with } \\
15 \mathrm{kWh} / \mathrm{m}^{2} \text { per year for residential over } \\
\text { the highest performing static glazing [84]. } \\
\text { EnergyPlus software was used to simulate } \\
\text { annual energy performance of the } \\
\text { dual-band electrochromic (DBEC) glazing } \\
\text { and indicated that DBEC is capable of } \\
\text { achieving annual primary energy savings } \\
\text { between } 64.5 \text { and } 322.9 \mathrm{kWh} / \mathrm{m}^{2} \text { of } \\
\text { window area from reduced heating, } \\
\text { cooling, and lighting demand [58]. }\end{array}$ & - & - \\
\hline
\end{tabular}




\subsection{Kinetic External Shading Systems}

Kinetic shading systems follow the same concept as dynamic facades and were introduced to satisfy some of the energy characteristics of the building envelope. The Lawrence Berkeley National Laboratory (LBNL) in the U.S. describes kinetic shading systems (dynamic façades) as systems that enable a building to reduce its lighting and cooling loads [85]. The development of these systems was a response to the growing awareness of energy reduction in buildings. Their adaptability offers the potential to achieve an energy-efficient environment, improve the comfort, balances indoor environmental quality (IEQ), such as, reduced glare, view to outside, privacy, thermal comfort and air quality and increase satisfaction and productivity of the occupants while minimizing the energy cost and environmental impact [86-88].

The systems move in response to mechanical, chemical or electrical stimuli by which folding, sliding, expanding, shrinking and transforming in the shading devices take place [89].

The development of kinetic facades presented in the literature are mainly concerned with the functional possibilities and enabling technology [37]. The mechanism in the kinetic shading depends on mechanical, chemical and electrical engineering where folding, sliding, expanding, shrinking and transforming in the shading devices takes place $[89,90]$. In this literature review the dominant types; rotating and folding shading systems have been explored.

\subsubsection{Rotating Shading Systems}

\section{(a) Design Principle and Performance}

As discussed earlier, rotating shading systems consist of a shading device made of either glass, metal, fabric or timber and is designed to rotate around either a horizontal or vertical axis depending on the position of its slates [91].

Glass lamella device have a better utilization of daylight over other systems [92]. The rotational movement of kinetic facades creates slow responses on every panel of the facade, which prevents any noise or distraction for the building's occupants throughout the day [88]. The influence of external dynamic louvers with light dimming strategies in an office building at hot and humid climate in Abu Dhabi, UAE was explored. The results showed that the dynamic louvers with inclination angle of $-20^{\circ}$ for the south had $30.31 \%$ energy savings, while with a $20^{\circ}$ inclination angle for the east and west orientations the savings were $34.02 \%$ and $28.57 \%$, respectively [93]. Similarly, a new double skin façade with movable integrated shading louvers was investigated and showed that during the entire year the proposed façade significantly improved the building energy behavior, especially when the winter configuration forced convection was considered [94].

The cooling and heating energy savings of four types of kinetic façade systems; the overhang, folding, horizontal louver, and vertical louver were investigated by Kensek and Hansanuwat (2011) at hot climate in California in U.S. It was found out that the most optimal shades are overhang and horizontal louvers and were able to rotate for 90 degrees, and decreased the energy consumption by $33 \%$ for cooling and $30 \%$ for heating [95].

\section{(b) Material}

The rotating shading devices are made of different materials, but predominantly use: (i) glass louvers, (ii) metal louvers and (iii) timber louvers. Examples of building applications with their performance are illustrated in Table 3.

(c) Carrier system of the shading device

The carrier system of the shading device may vary depending on the application type, the size of the louver and the span (Table 4). 
Table 3. Application of materials of external shading systems.

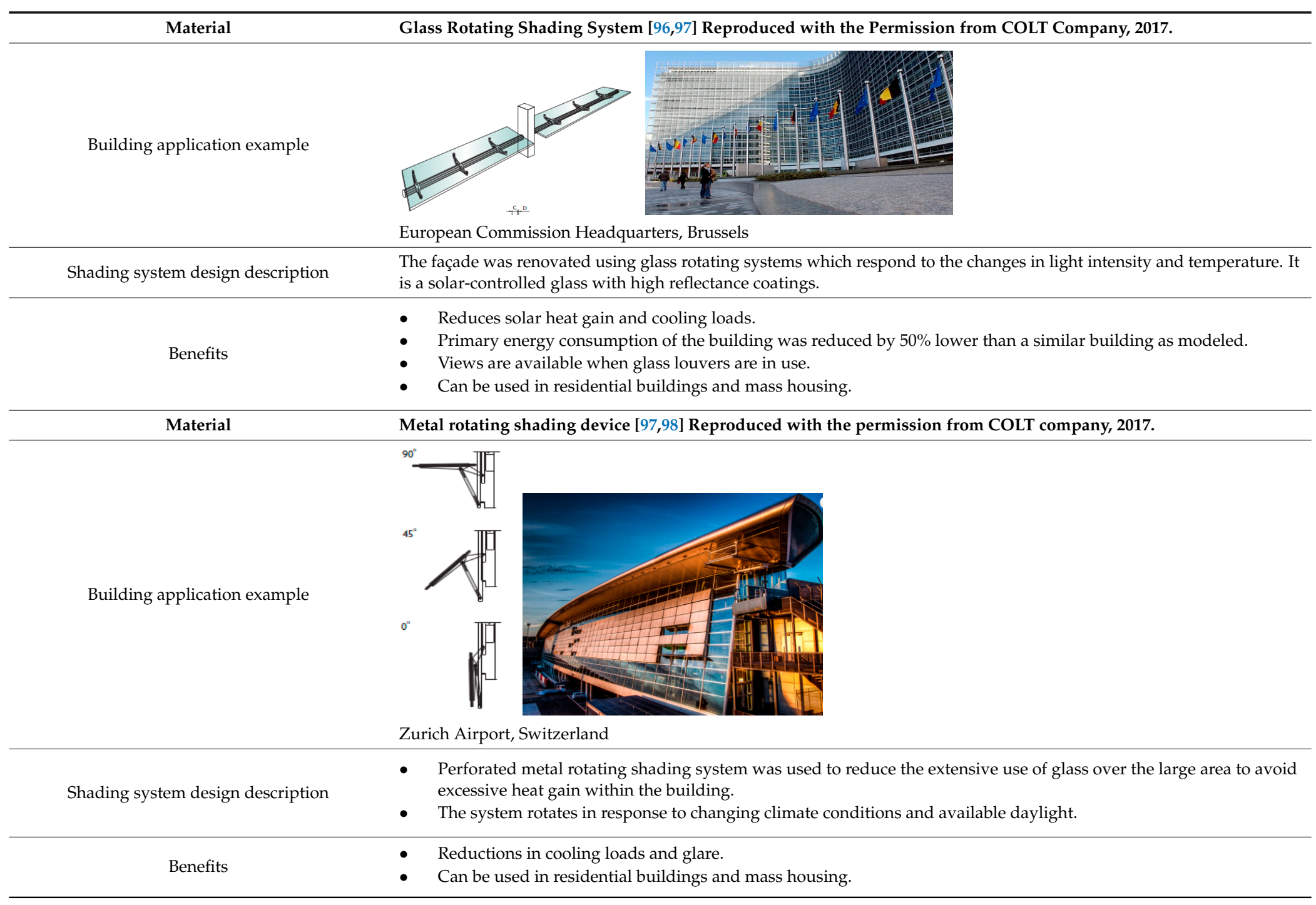


Table 3. Cont

\begin{tabular}{l}
\hline Material \\
\hline Anodized aluminum shading device [99] Reproduced with the permission from COLT company, 2017. \\
Building application example \\
University of Potsdam, Germany \\
\hline Vertically folding shutters which open and closed according to the position of the sun. \\
Benefits \\
$\begin{array}{l}\text { - Desthetical kinetic appearance for the building. } \\
\text { - Reduction in cooling energy and glare from direct sunlight. }\end{array}$ \\
\hline
\end{tabular}


Table 4. Carrier systems of shading device.

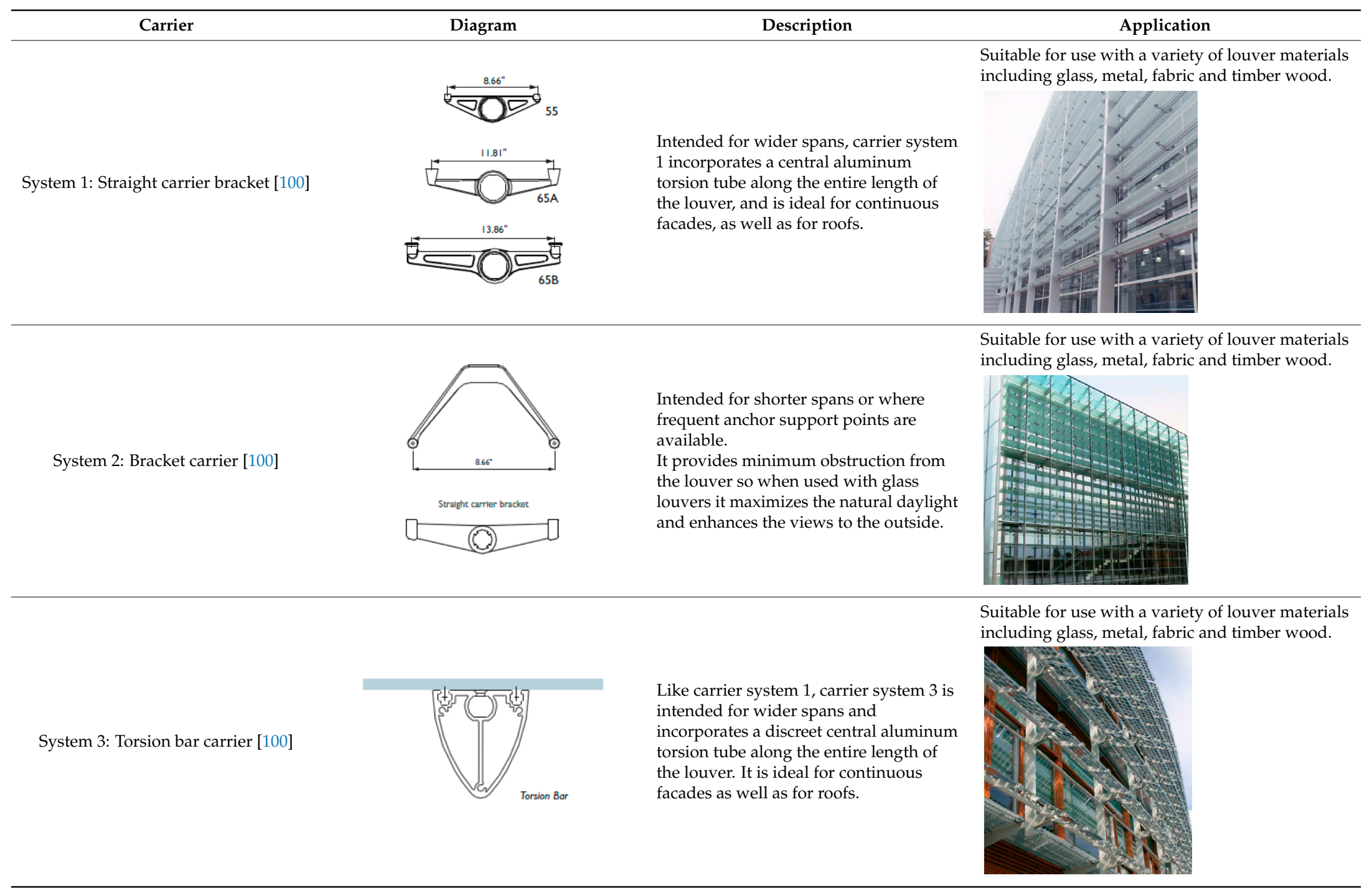


Table 4. Cont.

Carrier




\subsubsection{Folding Shading Systems}

(a) Design Principle and Performance

An effective type of shading systems is the shape morphing solar shading also called the folding shading system or the Origami shading device. This type of shading had been applied in several engineering fields, in adjustable and reconfigurable structures. Folding geometries have been used in biomedical devices [101], and in space and aircraft applications [102]. However, in architecture the use of folding Origami has only been recently experimented, especially as a shading device. When installed, they usually have different typologies of movement such as, translation, rotation and scaling, where external forces are required. Recent trends in shading device design have been trying to replace traditional mechanical systems with integrated multifunctional and smart actuators and are responsible for moving or controlling the mechanism [103].

Usually, sensors are able to analyze the variation of an external stimulus and transfer the information to the actuator, which provides the structure with a change in one of its properties $[104,105]$. The application of shape morphing solar shading in buildings depends on the following criteria that are considered to identify and analyze in detail the most suitable smart materials [106]:

- Corrosion resistance.

- Durability (life cycle of the smart movement/shape memory effect)

- Stimulus responsiveness (solar radiation, outside air temperature, electrical stimulus)

- Workability (process and adaptability)

- Achievable movements

- Impressing force

(b) Material

Recently, there are no solar shading devices that are entirely made of smart materials due to the material properties and costs. Therefore, smart materials are still used either as sensors or as actuators.

The types of smart materials of folding shading systems (either sensors or actuators) are illustrated in Figure 2 [106].

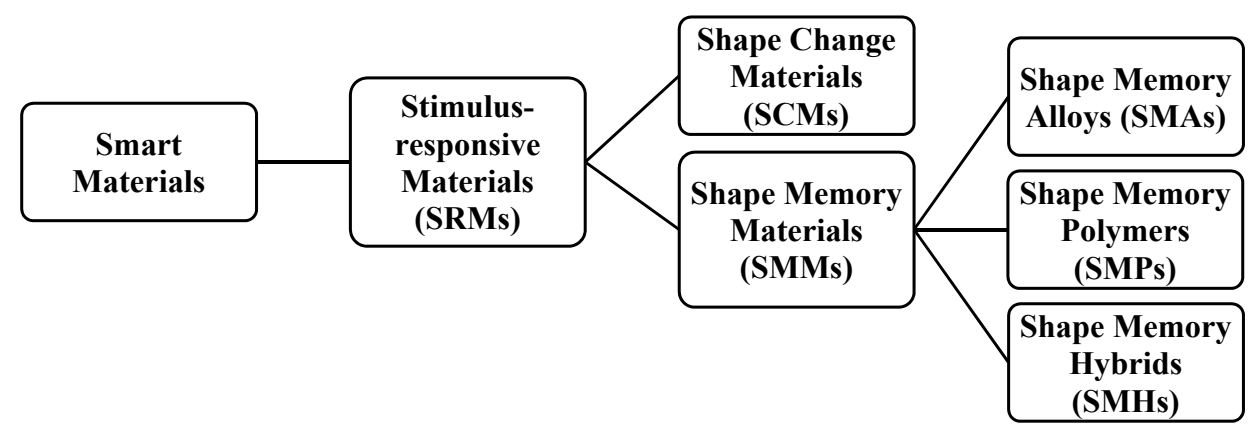

Figure 2. Smart materials types for folding shading systems.

Stimulus-responsive materials (SRMs) are the most suitable smart materials for shape morphing solar skins. This is due to their ability to respond to external stimulus through a change of their physical or chemical properties [107]. This type of smart materials is grouped into two main types as shown in Figure 2:

1. Shape change materials (SCMs) [106]: They are able to change their shape when right stimulus is present commonly a potential difference.

2. Shape memory materials (SMMs) [106]: "They are included in all the materials that are able to hold the modified shape until the appropriate stimulus is applied to activate the shape recovery cycle" $[107,108]$. Usually, those materials are activated by a difference in temperature. 
A study compared, described and listed the properties of the three types of SMMs that are used either as sensors or actuators for solar shading devices [106]. The comparison showed that the SMPs is the most promising system, due to the fact that their global deformation is sensibly higher $(800 \%)$ than Shape Memory Alloys (SMAs) (up to 10\%) and Shape Memory Hybrids (SMHs) (up to 6-8\%). However, in the time being, SMAs are the most durable shape memory materials since they are able to exceed 200,000 cycles, where SMPs have been tested only up to 200 cycles and SMHs have not undergone any tests [106].

\section{(c) Building Applications}

There are different types of shape morphing shading systems that can be applied in buildings. They usually move in response to variable external conditions, and they have the ability of minimizing energy required to perform adaptation. The movement of the folding shading systems has two main typologies [106]:

1. Translational movement which performs a bi-dimensional change of shape. It is linear and allows adjustment levels in the building skins by size-opening variation and by overlapping layers.

2. Rotational movement which performs a tri-dimensional change of shape; and performs swivel motion both in the same axis and/or around a different axis.

In both typologies an actuator is required, and it can be completely embedded into the device or strategically located to trigger a specific action. The different typologies of folding shading devices applied in buildings are shown in Table 5 .

Table 5. Different types of folding shading systems.

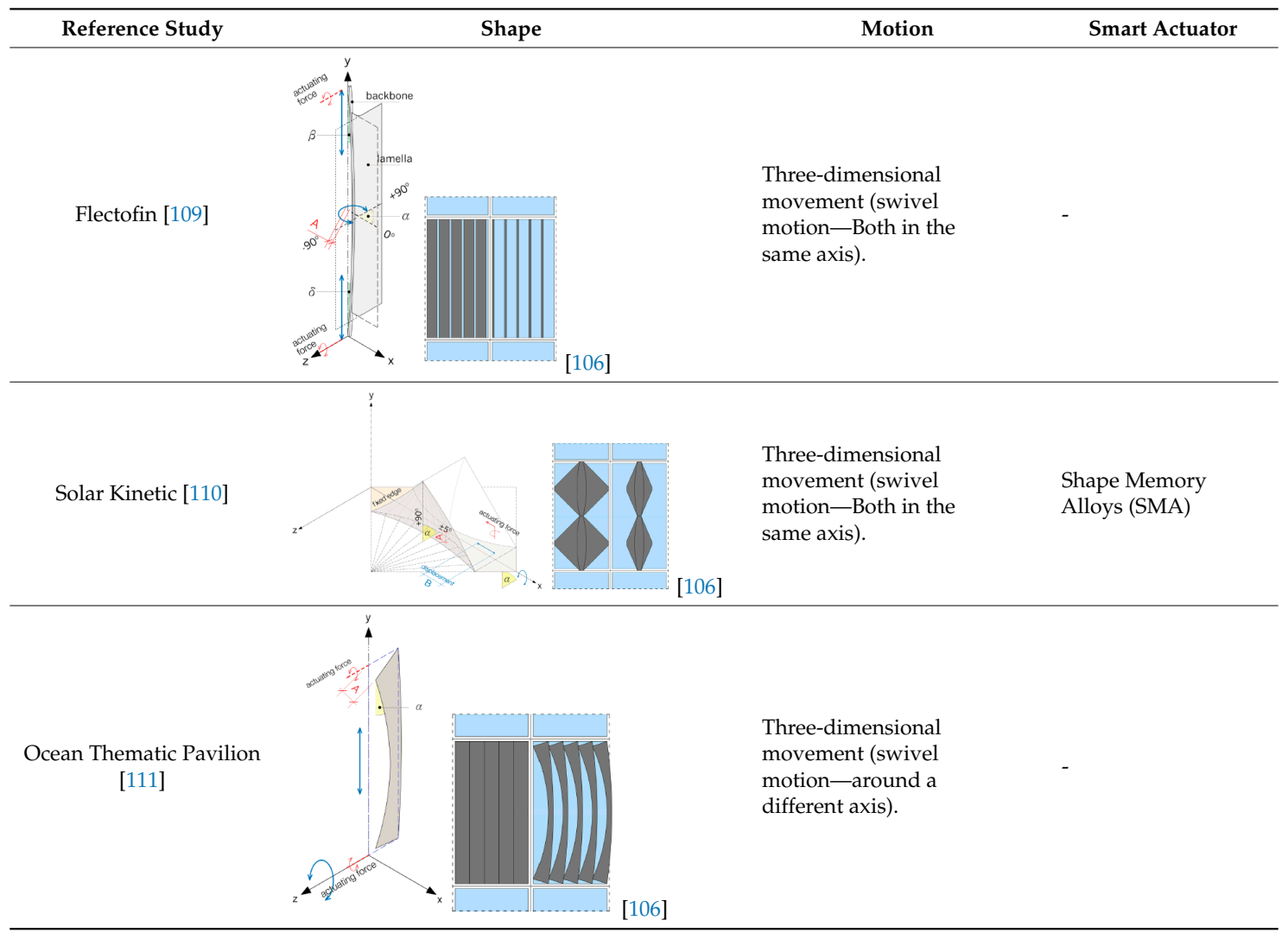


Table 5. Cont.

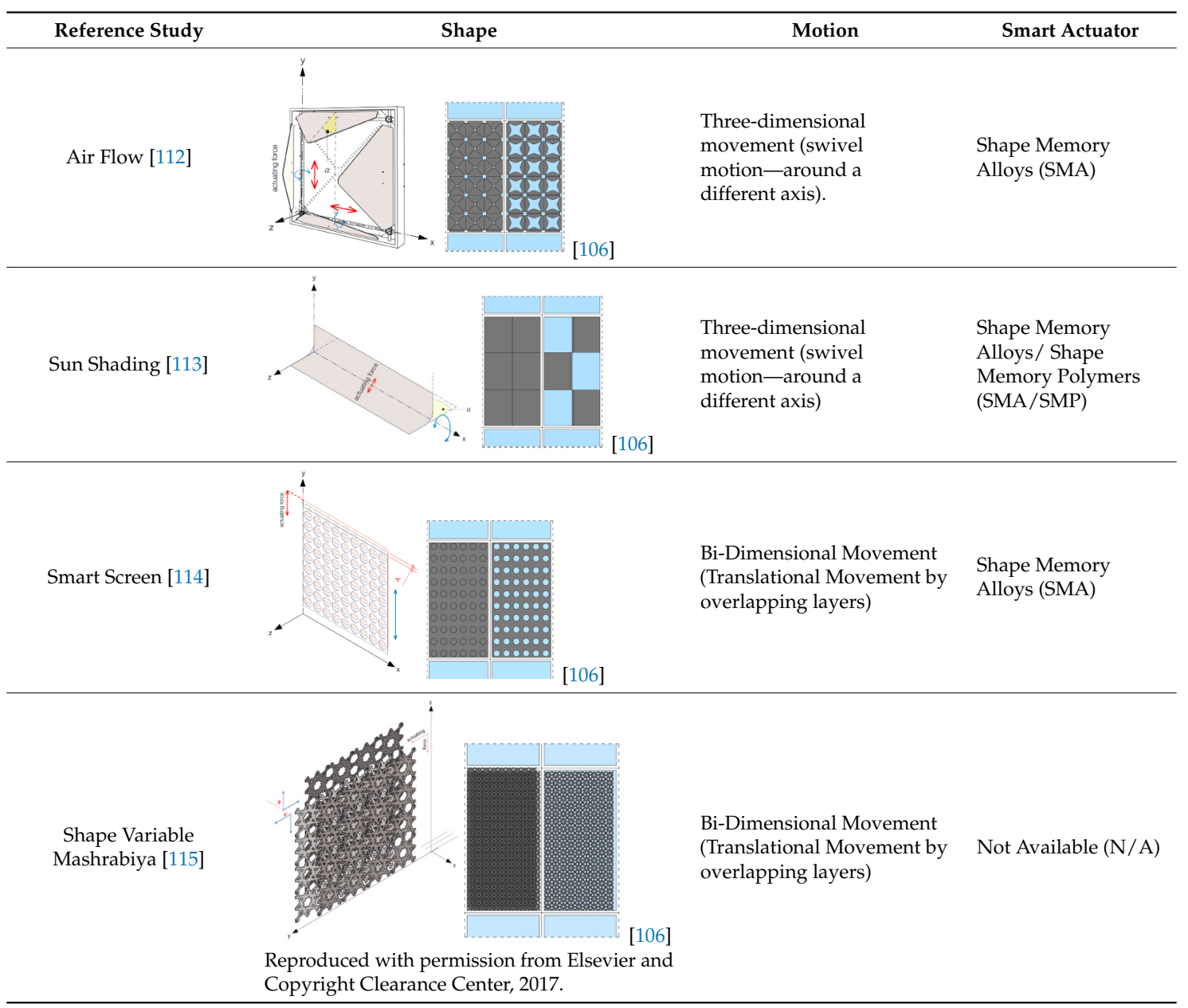

\subsection{Integration of Renewable Energy Systems}

\subsubsection{PV Integrated Shading Device}

\section{(a) Design Principle and Performance}

The integration of PV materials into shading systems was introduced in 1998 [116]. Integration of renewable energy generation can be applied in a very effective way in the shading devices, combining a dual benefit: shading and production of electricity. Integrated PV shadings could be used to provide energy controlling shape morphing devices.

Several studies were done on integrating PV panels as solar shadings and providing maximum PV performance. Researches were carried out different studies during 2002 and 2011 about integrating PV in the building as shading devices, the results showed that the use of BIPV as exterior solar shading devices produces on-site electricity and reduces cooling loads by $10 \%$ and $9.2 \%$ in building $[117,118]$. In another study, a prototype of a PV-integrated shading device on venetian blinds was built and monitored, where each blind consisted of a glazed static concentrator and of crystalline silicon bifacial solar cells. The result showed that the efficiency of PV cells was improved by $85 \%$ and represented a very good result for facades' applications [119].

Building integrated PV (BIPV) systems are used for generating electricity and as shading devices, they can be integrated into the building envelope, such as the roof, cladding, window shading, semi-transparent windows and façades. Additionally, they can reduce the use of building materials and electricity costs, reduction in use of fossil fuels and emission of ozone depleting gases [120]. 
Visual and the thermal performances of transparent BIPV on windows have been compared and revealed that in residential buildings in hot humid climate regions BIPV with slat angles of $60^{\circ}$ and $68^{\circ}$ provided good visual and thermal effect [121]. Mandalaki et al. also carried out several studies during 2012 and 2014 in hot climatic conditions on the visual and thermal comfort of PV-integrated with fixed shading devices. It was found out that shading devices with integrated south facing PV can produce electricity to be used for lighting and that the theoretical efficiency of $12 \%$ is satisfactory for simple geometries [41].

A prototype of a solar-powered automatic shading device was built and tested in Indonesian climatic conditions. The results showed a $3{ }^{\circ} \mathrm{C}$ decrease in the indoor air temperature due to the control of incoming solar radiation [122]. Kim et al. performed a study on a PV-integrated adjustable shading device combined with daylight responsive dimming system in Korea and results showed $32 \%$ increase of power production and a 35\% reduction of energy consumed by lighting systems [123].

\section{(b) Building applications}

The design characteristics of shading devices (SDs) with integrated photovoltaic panels (PVs) for residential building facades were studied for cooling and heating weather conditions in Crete. The results defined the best position PV-integrated shading devices according to the best lighting levels for tasks [124]. Thirteen different forms of monocrystalline PV panels mounted on south-facing shading devices of office buildings in Mediterranean region were evaluated [125]. The results showed that the best form of shading device integrated with PV was the "Brise-soleil full façade" which had the best optimization in the heating, cooling and lighting loads [125]. Integration of PV panels on louvers is another alternative in which the blade is exposed to provide full ventilation and can be tilted to maximize the efficiency [126]. The integration of PV panels on several fixed shading systems was tested by Mandalaki et al. (2014) for cooling purposes in Crete and found that the Brise-Soleil systems is the most efficient system where it ensures visual comfort and sufficient energy production [126].

\subsubsection{Solar Collectors Integrated Shading Devices}

\section{(a) Design Principle and Performance}

Solar collectors are used in buildings to reduce energy consumption and carbon emissions [127]; they are usually installed on building facades, roofs, balconies, awnings and outdoor spaces, which are called building-integrated solar thermal (BIST) systems [128,129]. Integration of solar collectors with exterior shading devices can reduce solar radiation and at the same time generate heat.

Solar collector devices have been investigated in some researches, and research methods typically include heat output estimation, numerical model calculation $[43,130]$ and simulation analysis [131].

A study integrated shading device with a solar thermal system for water heating and analyzed the system in buildings in temperate and Mediterranean climatic conditions of Portugal and Spain [132]. The two cases were compared; a real case that has a completely sunlit louver and two shaded louvers, and an ideal one with three completely sunlit louvers. For the real case, the shadings reduced transmitted energy by $7 \%$ for the $15^{\circ}$ inclination on horizontal plane, $12 \%$ for the $30^{\circ}$ inclination and $17 \%$ for the $45^{\circ}$ inclination. For the ideal case, the optimum angle was $25^{\circ}$ [132]. The payback period was 6.5 years and the $\mathrm{CO}_{2}$ savings was 8.6 tons [132].

\section{(b) Building applications}

A full-size prototype of solar collector was installed on a shading louver and showed that when the solar radiation was enough, the systems did not require auxiliary heating equipment and the performance was $20 \%$ more than the performance of conventional solar collectors with natural circulation function [133].

The integration of solar collectors in buildings at hot and humid weather in Kuala Lumpur has been investigated by Saadatian et al. and the results highlighted that there are several ways of 
integration including mounting on a structure on the roof or window separated from the building or superimposed, where the collectors are mounted on a structure of the building envelope and are arranged in parallel [134].

Another study evaluated the heat pipe solar collector attached on a louver under a range of climatic conditions in the UK [133]. The indoor experimental results showed the performance of the new design to be very promising, even though the collector materials were not carefully selected. Increased collector efficiency can be achieved by increasing the number of heat pipes in the louver with only minimal increase in louver cost [131].

\subsubsection{Algae Façade Systems}

\section{(a) Design principle}

Algae façade systems grow micro-algae in order to generate heat and electricity and are used as external cladding elements and dynamic shading devices [42]. Double skin façades were developed for the purpose of protecting curtain walls from the sun. Several transparent façade technologies have been introduced in buildings, such as insulated glass unit (IGU) and shading device (such as stretched metal, frit, suspended film) [135]. The use of those technologies in buildings is to protect the building from excessive heat gain and improve the performance of the building. However, those technologies are not enough for achieving high performance building. In order to do that, energy generation must be achieved from the integration of those technologies; such as Photovoltaic and solar thermal systems. As an alternative for high performance facade, an algae facade system has been introduced.

Kim investigated the algae façade system, which consists mainly of an algae panel, aluminum framing and algae growing apparatus in the University of North Carolina in the U.S. as illustrated in (Figure 3) [42]. The size of the system is $1.5 \mathrm{~m}$ wide by $3.65 \mathrm{~m}$ tall or taller depending on building conditions, consisting of both vision zone and algae zone [42]. The purpose of the clear vision zone is for view, daylight and ventilation, while the algae zone is for growing algae. The algae growing apparatus is comprised of intake systems for supplying $\mathrm{CO}_{2}$, and growing algae (e.g., algae, nutrients, medium etc.) and discharging systems for emitting $\mathrm{O}_{2}$ and collecting grown algae [42]. The mechanism of work in this system is achieved first by water being filled in the vertical glass louvers that contains nutrients which convert daylight and $\mathrm{CO}_{2}$ to algal biomass through the bio-chemical process of photosynthesis; at the same time the water is being heated up. Secondly, the biomass and the heat that is generated by the façade elements are transported by a closed loop system to the plant room, where both forms of energy are exchanged by a separator and a heat exchanger respectively. The temperature levels of the heat generated can be adjusted by using a hot water pump for the supply of hot water and for heating the building [136].

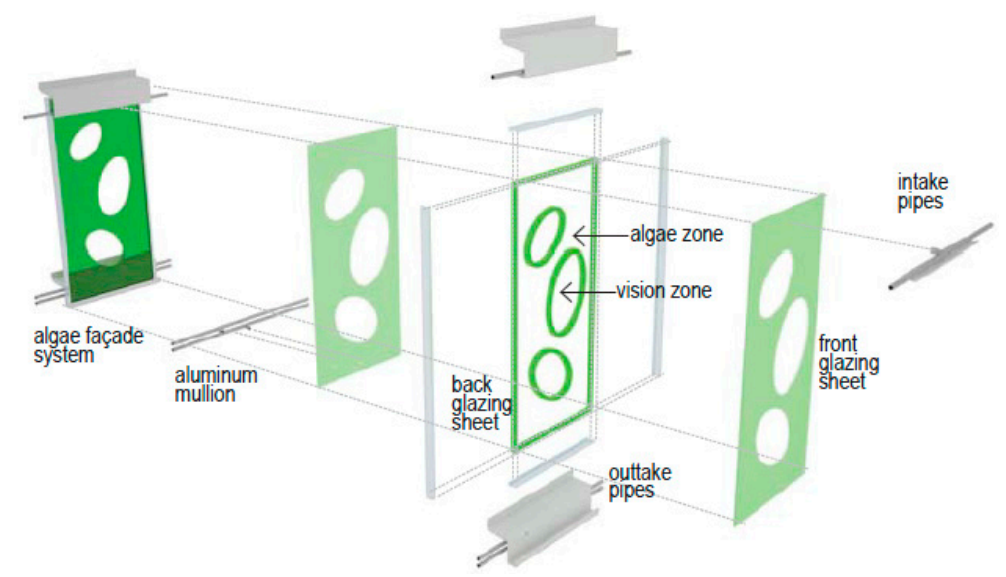

Figure 3. Algae façade system details [42]. Reproduced with the permission from author Kyoung-Hee Kim. 


\section{(b) System Performance}

Kim has performed a few studies about the performance of algae façade systems. In one of the studies [42] the aim was to identify the feasibility of the algae façade system through schematic design and prototyping. The mechanism of algae facades was explained. Tests were conducted in a sunny winter noon in outdoor environment using a FLUKE (2006, SmartView (Version 3.2), NC, USA) thermography system with its software package. The result showed that the algae façade system has the future potential for sustainable façade alternatives and energy generation possibilities. The computer simulation on structural behaviors provided alternative design solutions to meet stress and stiffness criteria under various loadings, in addition to fabrication challenges associated with watertight interfaces between the vision zone and the algae zone [42]. Another study by Kim about bio-facades or algae façade systems showed a retrofitting case of a building [137]. The result showed that the algae facades reduces the energy consumption and $\mathrm{CO}_{2}$ emissions, where the retrofitted building energy consumption was reduced by $30 \%$ compared to an existing building due to the thermal and daylighting performance improvements. Moreover, the retrofitted façade reduces the life cycle cost by $\$ 110,000$ and reduces the life cycle by 200 tons, and $\mathrm{CO}_{2}$ generation due to the photosynthesis process, which was 150 tons over the 30-year life cycle [136].

Usually, about $40{ }^{\circ} \mathrm{C}$ heat is obtained from the façade and is either used directly to heat water or stored in the ground to be used in a geothermal system. The efficiency of the conversion of light to biomass is $10 \%$ and to heat $38 \%$. For comparison, photovoltaic systems have an efficiency of $12-15 \%$ and solar thermal systems 60-65\% [136]. Therefore, algae façade is a competitive opportunity relative to these other technologies. Additionally, the algae façade helps improve the overall $\mathrm{CO}_{2}$ balance by removing $\mathrm{CO}_{2}$ from flue gas at quantities equivalent to the build-up of biomass [136].

\section{(c) Building applications}

The first algae façade integrated in a building was in the BIQ which is a part of the International Building Exhibition (IBA) 2013 in Hamburg, Germany [136]. The building used 129 "bioreactors" or algae façade, when sunlight hits the facade, photosynthesis process causes the microorganisms to multiply and causes the water to go about $40{ }^{\circ} \mathrm{C}$, the heat then stored to be used for other uses [136]. Currently, the building reduces the overall energy needs by $50 \%$, and the designer of the system says $100 \%$ is achievable by combining it with solar panels to power the pumps and heat exchangers [136].

Another application of the algae façade system was in the GSA Federal Building in Los Angeles that won first place scheme for the 2011 Ideas competition, where an "algae photo bioreactor tube" was attached to the top surface of the opaque building envelopes [136]. Similarly, the same company made a net energy zero Battery Park project in San Francisco that applied "algae photo bioreactor panels" to grow algae and reduce $\mathrm{CO}_{2}[136]$.

\section{Controls of Active Shading Systems}

The control of the movement of dynamic shading can be either user manual control strategy or automatic control strategy.

\subsection{User Control Shading Devices}

Shading devices in buildings are linked to occupants' behavior. There are many studies that focused on the relationship between user comfort and shading operation.

Most of the researches done on user's response to these systems are related to the manual use of blinds [138]. A survey explored the factors that affect the occupants' comfort in Danish residential buildings [139]. The results suggested that most of the occupants preferred manually-controlled, especially for artificial light, windows opening and solar shading [139]. In another study, 800 building occupants were interviewed, and $90 \%$ preferred the use of automatic blinds because they thought they provided a better indoor quality [140]. The position of remotely controlled blinds in eight individual 
offices for 30 weeks was evaluated and showed that remotely controlled blinds were used three times more often than manually controlled ones [141].

Galasiu and Veitch pointed out that the results of the studies on manually operated blinds are helpful in favoring automated ones in Ontario, Canada [142]. Reinhart and Voss studied the reasons that trigger occupants' reaction to shading devices in Germany and found out that they tend to close their blinds to avoid direct sunlight above $50 \mathrm{~W} / \mathrm{m}^{2}$ on the work plane surface [143].

Wienold analyzed different shadings control strategies in Germany in order to design a shading system based on real user behaviors and the result showed that when a manual control is provided especially in summer, the shading device is rarely activated [144].

It was claimed that occupants had a positive experience when automated dynamic shading was applied [145]. It is concluded that automated control strategies of shading systems are preferred and are more beneficial in buildings.

\subsection{Automatic Control Strategies}

The use of sensors and actuators for controlling the movement of dynamic shading devices is more beneficial when it comes to adapting to various external environmental conditions. Control strategies and advanced control shading systems have positive impact on both the occupants' comfort and the energy performance of the building [146].

The operation of the façade components could be by occupancy, environmental variable, time or utility price signals. Two types of loop controls can be used in buildings; open and closed loop control systems $[147,148]$. The open loop motorized shading systems working mechanism depends on the pre-calculated angle of incidence of sun light [149-151], or the illuminance sensor measurements of the façade [143]. The control of the shading is based on three main types of control algorithms that depend on the performance criteria they address [30]:

1. Threshold controllers: where the shading device gets activated when an external solar illuminance or irradiance limit is exceeded.

2. Sun blocking controllers: moves the shading system or adjust the blind slat angle depending on the sun position.

3. Mode and scene controllers: use a variety of sensors and different control algorithms [30].

Three types of control of the external shading devices were analyzed [152]. The first type was based on external vertical irradiation level only; the second type was based on the interior temperature level only, while the third type was the most effective one which was a combination of both types. The external shadings are closed when both conditions are met and opened when at least one of the conditions is met. A scaled model was built to test two types of control strategies for external venetian blinds [153]. One strategy provided maximum slat openness, while the other one provided maximum work-plane illuminance. The results indicated that for the low ground reflectance the energy savings was $38.1 \%$, while for the high ground reflectance, the energy savings was $55.3 \%$. Bauer et al. developed a logic based control algorithm that minimized thermal and artificial lighting energy demand [154]. The result showed that the smart blind controller achieved saving of $11 \%$ for the artificial lighting and between $20 \%$ and $50 \%$ savings for heating/ cooling. A significant application of sensors application in buildings is the case of the "Arab World Institute" in Paris, which is the one of first buildings to apply sensor based automated response shading systems based on the environmental conditions. The lens opens or closes according to the light quality inside the building. The system consisted of photosensitive mechanical automated devices, 30,000 light sensitive diaphragms on 1600 elements, which function like, a lens of the camera and all the mechanical devices are connected to a central computer [155]. Examples of innovative controls of shading devices that depends on different strategies for their movement are discussed in Table 6 below. 
Table 6. Innovative shading control systems.

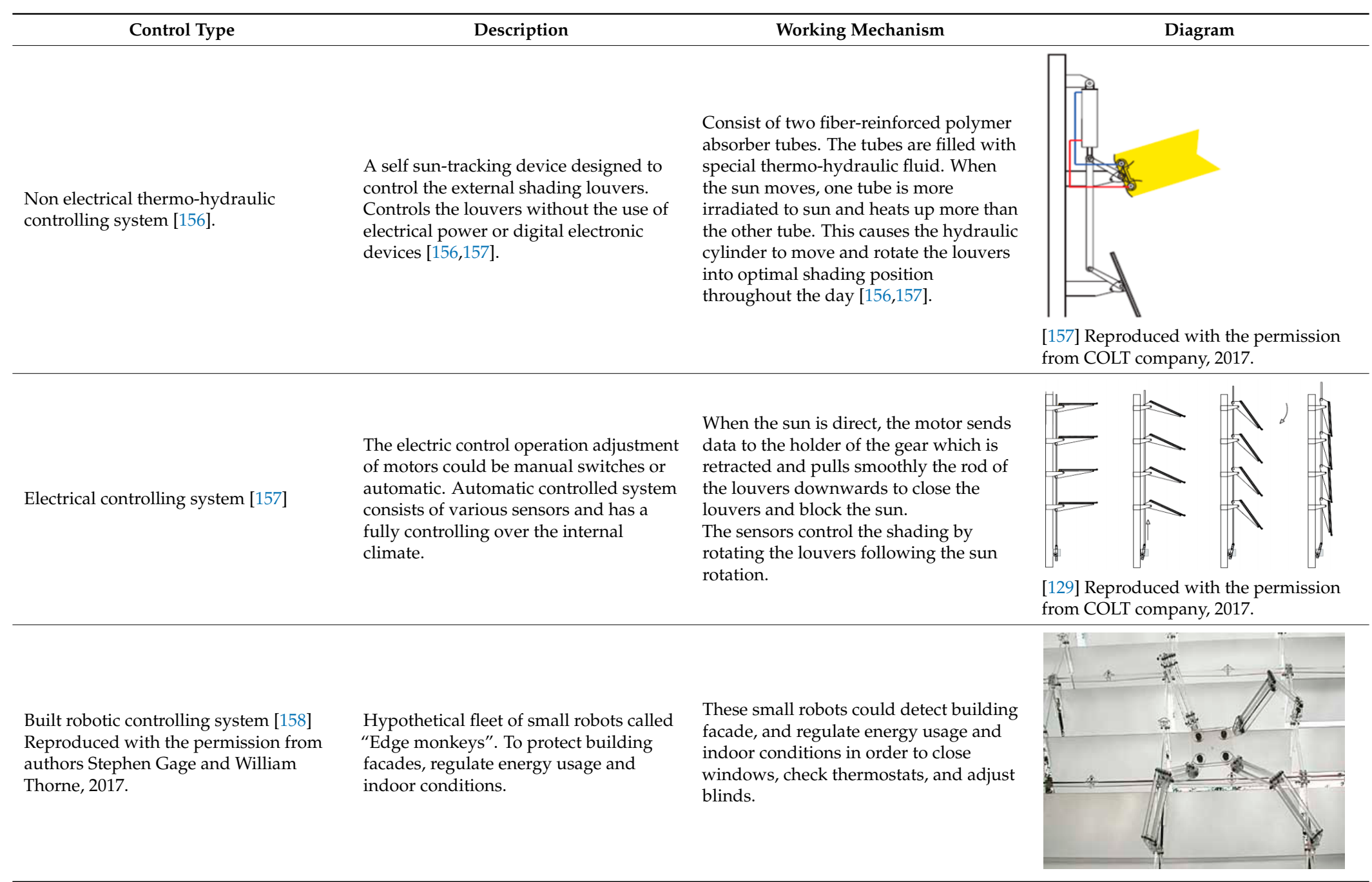




\section{Challenges, Limitations and Future Opportunities in Active Shading Systems}

The application of dynamic smart shading has grown widely in order mitigate the building conditions against excessive heat gain and glare. However, there are some challenges inherent to these systems that should be considered in future research. Challenges, limitations and opportunities of active shading systems are discussed in Table 7.

Table 7. Challenges and future developments of dynamic shading systems.

\begin{tabular}{|c|c|c|}
\hline Dynamic Shading Type & Challenges and Limitations & Opportunities and Development \\
\hline Electrochromic Glazing & $\begin{array}{l}\text { - High initial cost (between } 100-1000 \mathrm{US} \$ / \mathrm{m}^{2} \text { ) and is more } \\
\text { expensive than other smart glazing types [44]. } \\
\text { High labor and maintenance cost compared to other } \\
\text { conventional glazing types [44]. } \\
\text { - The optical properties that change the Near-infrared } \\
\text { switching electrochromics (NIC) are still little known [68]. } \\
\text { - The performance of the NIC glazing might be affected by } \\
\text { the present climate changes [68]. } \\
\text { - Low durability (sensitive to UV) [159] } \\
\text { High increased surface temperature and slow coloration } \\
\text { process [160]. }\end{array}$ & $\begin{array}{l}\text { - Improve the Electrochromic glazing life time } \\
\text { expectancy and durability to be similar to } \\
\text { those of standard coated windows [44]. } \\
\text { Develop faster switching speeds }(<5,6 \mathrm{~min}) \text { in } \\
\text { order to promote better savings in energy and } \\
\text { occupants' visual comfort [161]. } \\
\text { Develop higher visible transmittances in the } \\
\text { bleached state }(\tau V>0.6) \text { to allow more } \\
\text { daylight [161]. }\end{array}$ \\
\hline SPDs & $\begin{array}{l}\text { - Lower transparency in the SPDs' bleached state, } \\
\text { compared with the EC glazing [48]. } \\
\text { - Undesirable haze [48]. }\end{array}$ & $\begin{array}{l}\text { - Improve the properties of the SPD glazing } \\
\text { and increase its transparency. } \\
\text { - } \quad \text { Remove haze from the SPD glazing. } \\
\text { Further research is required on the integration } \\
\text { of SPD glazing in buildings. }\end{array}$ \\
\hline LCD & $\begin{array}{l}\text { - LCD glazing is hazy because it scatters rather than absorb } \\
\text { light, so there is a fog factor even when the device is in } \\
\text { transparent state [44,82]. } \\
\text { LC glazing is either transparent or opaque with no } \\
\text { in-between states [44]. }\end{array}$ & $\begin{array}{l}\text { - } \quad \text { Remove the haze from the LCD glazing. } \\
\text { Improve the properties of the LC glazing to } \\
\text { have intermediate states between opaque and } \\
\text { transparent states. } \\
\text { Investigate the application of the emerging } \\
\text { (GDLC) which less haze and yellowing than } \\
\text { conventional LCDs in different climate } \\
\text { conditions [78]. } \\
\text { Carry out further researches on the } \\
\text { integration of LCD glazing in buildings. }\end{array}$ \\
\hline Folding shading systems & $\begin{array}{l}\text { Variable external conditions could limit the efficiency and } \\
\text { the movement of the folding shading systems [106]. } \\
\text { The behavior of the SMPs is limited to one-dimensional } \\
\text { deformation which limits their movement [162]. }\end{array}$ & $\begin{array}{l}\text { - Further studies should be undertaken on the } \\
\text { use of shape memory actuators in the } \\
\text { building industry; life cycle, solar activation, } \\
\text { and resistance to external weather } \\
\text { conditions [106]. } \\
\text { - Further research on the use of smart materials } \\
\text { with dynamic shading devices [106]. } \\
\text { - Further research on the control of the folding } \\
\text { shading systems in response to the } \\
\text { climate variations. }\end{array}$ \\
\hline PV mounted shading & $\begin{array}{l}\text { - Higher temperatures will decrease the power production } \\
\text { of the PV panels. } \\
\text { Dust accumulation and limited tolerance to overheating } \\
\text { will restrict the expected performance and lower } \\
\text { the efficiency. } \\
\text { - Gap in PV shading systems in Mediterranean countries } \\
\text { where the amount of solar radiation is high. }\end{array}$ & $\begin{array}{l}\text { - Further research required on cost assumption } \\
\text { of PV shading systems, particularly for } \\
\text { movable PV shading devices. } \\
\text { To investigate materials that have long-term } \\
\text { durability and can stand the various climate } \\
\text { conditions (Snow, heat, dust, wind and air } \\
\text { tightness) [163]. }\end{array}$ \\
\hline Algae Façade System & $\begin{array}{l}\text { - High initial cost (approximately } \$ 2500 \text { per square meter } \\
\text { for the bioreactor system alone) [164]. } \\
\text { - High maintenance cost. }\end{array}$ & $\begin{array}{l}\text { - More research is required on working } \\
\text { mechanism alternates of the algae façade } \\
\text { systems in order to reduce their initial cost. } \\
\text { More research to test its performance under } \\
\text { several climate conditions. } \\
\text { As relatively new, the Verde system was } \\
\text { introduced in the market after the } \\
\text { development of algae façade system. Its main } \\
\text { function is to collect light and transfer it } \\
\text { through fiber optic cables, then algae is grown } \\
\text { within the bioreactor to generate energy. More } \\
\text { research is necessary to establish its properties } \\
\text { and part of the market [165]. }\end{array}$ \\
\hline
\end{tabular}




\section{Conclusions}

This paper reviewed the current status of active shading systems in buildings, exploring their design principle, performance, working mechanism and building application. Six types of active shading systems including the electrochromic glazing, the automated shading systems consisting of the rotating and folding shading devices and the shading systems that integrated renewable energy generation such as the PV, algae façade and solar thermal collectors were discussed. The design principle, performance and application of each system were explored. Additionally, the control strategies of the systems including user control automated control were reviewed. In this literature review, 165 papers were examined to evaluate the different types of active shading systems. The significant conclusions inferred from the reviewed studies states that:

1. The use of electrochromic windows is increasing; however, its high cost is still a challenge.

2. The electrochromic windows have always progressed in their performance and there is always an emergence of new types such as the NIR and POMs which have better performance. However, they are hindered by their high initial costs.

3. The use of folding shading systems is still limited because of the need of expensive smart actuators and sensors.

4. Rotating shading system is the most applied and studied system among active shading systems. Its low initial cost and available resources and materials including glass, metal, timber and fabric make it attractive.

5. The use of automatic control strategies has been proven to be much more effective than the use of manual user controlled systems due to the benefits they provide including the adaptation to the external conditions.

6. The use of robotic controlling systems and the thermo-hydraulic controlling systems are emerging automatic control systems that requires further investigation as there are limited number of studies done on their performance, building application and use in varying climate conditions.

7. Additionally, more studies should be done on the integration of PV panels on this emerging type of shading devices.

Furthermore researches must be done on to develop faster switching speeds of electrochromic glazing to increase energy savings. Additionally the SPDs and LCDs suffer from haze in the glazing, thus, further research must be carried out in order to decrease the haze and test their integration in buildings. The movement of folding shading systems could be limited by the variable external conditions, therefore further investigation under different climatic conditions is required. Finally, the algae façade system is a promising immerging system that needs further exploration in terms of performance and building application.

Acknowledgments: The authors gratefully acknowledge financial support from the United Arab Emirates University through the Emirates Centre for Energy and Environment Research funded research project (31R054).

Author Contributions: Kheira Tabet Aoul conceived and guided the review; Joud Al Dakheel conducted the literature data collection and analysis. Both authors wrote the paper.

Conflicts of Interest: The authors declare no conflict of interest. 


\section{Nomenclature}

$\begin{array}{ll}\text { PV } & \text { Photovoltaic } \\ \text { SPDs } & \text { Suspended particle devices } \\ \text { EC } & \text { Electrochromic devices } \\ \text { LCD } & \text { Liquid crystal devices } \\ \text { LEDs } & \text { Light emitting diodes } \\ \text { CEC } & \text { Conventional electrochromic glazing } \\ \text { NEC } & \text { Near-infrared Switching Electrochromic } \\ \text { DBEC } & \text { Dual-band Electrochromic } \\ \text { PSBP } & \text { Polymer-stabilized Blue Phase } \\ \text { PDLC } & \text { Polymer-dispersed Liquid Crystal } \\ \text { LCoS } & \text { Liquid crystal on silicon displays } \\ \text { OILC } & \text { Optically isotropic LC } \\ \text { GDLC } & \text { Gel dispersed liquid crystals } \\ \text { AC } & \text { Alternating current } \\ \text { IR } & \text { Infra-red } \\ \text { SHGC } & \text { Solar heat gain coefficient } \\ \text { Tv } & \text { Visible transmission } \\ \text { SC } & \text { Shading coefficient } \\ \text { ITO } & \text { Indium tin oxide } \\ \text { IEQ } & \text { Indoor environmental quality } \\ \text { SRMs } & \text { Stimulus-responsive materials } \\ \text { SCMs } & \text { Shape change materials } \\ \text { SMMs } & \text { Shape memory materials } \\ \text { BIPV } & \text { Building integrated PV } \\ \text { BIST } & \text { Building-integrated solar thermal } \\ \text { IGU } & \text { Insulated glass unit } \\ & \end{array}$

\section{References}

1. Boyce, P.; Hunter, C.; Howlett, O. The Benefits of Daylight through Windows; Rensselaer Polytechnic Institute: Troy, NY, USA, 2003.

2. Tabet, A.K. Windows functions and design: Daylighting, visual comfort and well-being. In Proceedings of the CIE 2012, Lighting Quality and Energy Efficiency, Hangzhou, China, 19-21 September 2012; pp. 555-565.

3. Edwards, L.; Torcellini, P.A. A Literature Review of the Effects of Natural Light on Building Occupants; National Renewable Energy Laboratory: Golden, CO, USA, 2002; p. 59.

4. Veitch, J.A.; Galasiu, A.D. The Physiological and Psychological Effects of Windows, Daylight, and View at Home: Review and Research Agenda; National Research Council Canada: Ottawa, ON, Canada, 2012.

5. Veitch, J.A.; Gifford, R. Assessing beliefs about lighting effects on health, performance, mood, and social behavior. Environ. Behav. 1996, 28, 446-470. [CrossRef]

6. Figueiro, M.G. Daylight and productivity: A possible link to circadian regulation. In Proceedings of the 5th International LRO Lighting Research Symposium-Light and Human Hearth, Palo Alto, CA, USA, 3-5 November 2002; pp. 185-193.

7. Mardaljevic, J.; Heschong, L.; Lee, E. Daylight metrics and energy savings. Light. Res. Technol. 2009, 41, 261-283. [CrossRef]

8. Krarti, M.; Erickson, P.M.; Hillman, T.C. A simplified method to estimate energy savings of artificial lighting use from daylighting. Build. Environ. 2005, 40,747-754. [CrossRef]

9. Wienold, J. Dynamic daylight glare evaluation. In Proceedings of the Building Simulation, Glasgow, UK, 27-30 July 2009; pp. 944-951.

10. Ander, G. Daylighting. Available online: http://www.wbdg.org/resources/daylighting (accessed on 8 June 2017).

11. Kirimtat, A.; Koyunbaba, B.K.; Chatzikonstantinou, I.; Sariyildiz, S. Review of simulation modeling for shading devices in buildings. Renew. Sustain. Energy Rev. 2016, 53, 23-49. [CrossRef] 
12. Soflaei, F.; Shokouhian, M.; Abraveshdar, H.; Alipour, A. The impact of courtyard design variants on shading performance in hot-arid climates of Iran. Energy Build. 2017, 143, 71-83. [CrossRef]

13. Michael, A.; Demosthenous, D.; Philokyprou, M. Natural ventilation for cooling in mediterranean climate: A case study in vernacular architecture of Cyprus. Energy Build. 2017, 144, 333-345. [CrossRef]

14. Chandel, S.S.; Sharma, V.; Marwah, B.M. Review of energy efficient features in vernacular architecture for improving indoor thermal comfort conditions. Renew. Sustain. Energy Rev. 2016, 65, 459-477. [CrossRef]

15. Kamarudin, Z. Long-roofed houses of northeastern peninsular Malaysia: Sustainability of its identity in the built environment. Procedia Environ. Sci. 2015, 28, 698-707. [CrossRef]

16. Al-Tamimi, N.; Fadzil, S.F.S. The Potential of Shading Devices for Temperature Reduction in High-Rise Residential Buildings in the Tropics. Procedia Eng. 2011, 21, 273-282. [CrossRef]

17. Ebrahimpour, A.; Maerefat, M. Application of advanced glazing and overhangs in residential buildings. Energy Convers. Manag. 2011, 52, 212-219. [CrossRef]

18. Tzempelikos, A.; Shen, H. Comparative control strategies for roller shades with respect to daylighting and energy performance. Build. Environ. 2013, 67, 179-192. [CrossRef]

19. Tian, C.; Chen, T.; Chung, T.M. Experimental and simulating examination of computer tools, Radlink and DOE2, for daylighting and energy simulation with venetian blinds. Appl. Energy 2014, 124, 130-139. [CrossRef]

20. Ye, Y.; Xu, P.; Mao, J.; Ji, Y. Experimental study on the effectiveness of internal shading devices. Energy Build. 2016, 111, 154-163. [CrossRef]

21. Dutta, A.; Samanta, A.; Neogi, S. Influence of orientation and the impact of external window shading on building thermal performance in tropical climate. Energy Build. 2017, 139, 680-689. [CrossRef]

22. Cho, J.; Yoo, C.; Kim, Y. Viability of exterior shading devices for high-rise residential buildings: Case study for cooling energy saving and economic feasibility analysis. Energy Build. 2014, 82, 771-785. [CrossRef]

23. Karlsen, L.; Heiselberg, P.; Bryn, I.; Johra, H. Solar shading control strategy for office buildings in cold climate. Energy Build. 2016, 118, 316-328. [CrossRef]

24. Aldawoud, A. Conventional fixed shading devices in comparison to an electrochromic glazing system in hot, dry climate. Energy Build. 2013, 59, 104-110. [CrossRef]

25. Konstantoglou, M.; Tsangrassoulis, A. Dynamic operation of daylighting and shading systems: A literature review. Renew. Sustain. Energy Rev. 2016, 60, 268-283. [CrossRef]

26. Lee, E.S.; Selkowitz, S.E.; Hughes, G.D.; Thurm, D.A. Market Transformation Opportunities for Emerging Dynamic Facade and Dimmable Lighting Control Systems; Lawrence Berkeley National Laboratory: Pacific Grove, CA, USA, 2004.

27. Ibraheem, Y.; Farr, E.R.; Piroozfar, P.A. Embedding passive intelligence into building envelopes: A review of the state-of-the-art in integrated photovoltaic shading devices. Energy Procedia 2017, 111, 964-973. [CrossRef]

28. Nielsen, M.V.; Svendsen, S.; Jensen, L.B. Quantifying the potential of automated dynamic solar shading in office buildings through integrated simulations of energy and daylight. Sol. Energy 2011, 85, 757-768. [CrossRef]

29. Skaff, M.C.; Gosselin, L. Summer performance of ventilated windows with absorbing or smart glazings. Sol. Energy 2014, 105, 2-13. [CrossRef]

30. Long, L.; Ye, H. Discussion of the performance improvement of thermochromic smart glazing applied in passive buildings. Sol. Energy 2014, 107, 236-244. [CrossRef]

31. Rezaei, S.D.; Shannigrahi, S.; Ramakrishna, S. A review of conventional, advanced, and smart glazing technologies and materials for improving indoor environment. Sol. Energy Mater. Sol. Cells 2017, 159, $26-51$. [CrossRef]

32. Dussault, J.M.; Sourbron, M.; Gosselin, L. Reduced energy consumption and enhanced comfort with smart windows: Comparison between quasi-optimal, predictive and rule-based control strategies. Energy Build. 2016, 127, 680-691. [CrossRef]

33. Allen, K.; Connelly, K.; Rutherford, P.; Wu, Y. Smart Windows-Dynamic Control of Building Energy Performance. Energy Build. 2017, 139, 535-546. [CrossRef]

34. Lai, K.; Wang, W.; Giles, H. Solar shading performance of window with constant and dynamic shading function in different climate zones. Sol. Energy 2017, 147, 113-125. [CrossRef] 
35. Skarning, G.C.J.; Hviid, C.A.; Svendsen, S. The effect of dynamic solar shading on energy, daylighting and thermal comfort in a nearly zero-energy loft room in Rome and Copenhagen. Energy Build. 2017, 135, 302-311. [CrossRef]

36. Manzan, M.; Clarich, A. FAST energy and daylight optimization of an office with fixed and movable shading devices. Build. Environ. 2017, 113, 175-184. [CrossRef]

37. Linn, C. Kinetic Architecture: Design for Active Envelopes; Images Publishing: Victoria, Australia, 2014.

38. Das, S.K.; Verma, D.; Nema, S.; Nema, R.K. Shading mitigation techniques: State-of-the-art in photovoltaic applications. Renew. Sustain. Energy Rev. 2017, 78, 369-390. [CrossRef]

39. Loonen, R.; Trčka, M.; Cóstola, D.; Hensen, J. Climate adaptive building shells: State-of-the-art and future challenges. Renew. Sustain. Energy Rev. 2013, 25, 483-493. [CrossRef]

40. Drozdowski, Z. The adaptive building initiative: The functional aesthetic of adaptivity. Archit. Des. 2011, 81, 118-123. [CrossRef]

41. Mandalaki, M.; Zervas, K.; Tsoutsos, T.; Vazakas, A. Assessment of fixed shading devices with integrated PV for efficient energy use. Sol. Energy 2012, 86, 2561-2575. [CrossRef]

42. Kim, K.H. Beyond Green: Growing Algae Facade. In Proceedings of the ARCC Conference Repository, Charlotte, NC, USA, 12-15 February 2014.

43. Matuska, T.; Sourek, B. Façade solar collectors. Sol. Energy 2006, 80, 1443-1452. [CrossRef]

44. Lampert, C.M. Smart switchable glazing for solar energy and daylight control. Sol. Energy Mater. Sol. Cells 1998, 52, 207-221. [CrossRef]

45. Baetens, R.; Jelle, B.P.; Gustavsen, A. Properties, requirements and possibilities of smart windows for dynamic daylight and solar energy control in buildings: A state-of-the-art review. Sol. Energy Mater. Sol. Cells 2010, 94, 87-105. [CrossRef]

46. Lee, E.S.; Tavil, A. Energy and visual comfort performance of electrochromic windows with overhangs. Build. Environ. 2007, 42, 2439-2449. [CrossRef]

47. Loonen, M.R.C.G.; Singaravel, S.; Trčka, M.; Cóstola, D.; Hensen, J.L.M. Simulation-based support for product development of innovative building envelope components. Autom. Constr. 2014, 45, 86-95. [CrossRef]

48. Barrios, D.; Vergaz, R.; Sanchez-Pena, J.M.; Garcia-Camara, B.; Granqvist, C.G.; Niklasson, G.A. Simulation of the thickness dependence of the optical properties of suspended particle devices. Sol. Energy Mater. Sol. Cells 2015, 143, 613-622. [CrossRef]

49. Sottile, G.M. Assessment of attitudes and expectations of switchable glass among United States window manufacturers. In Proceedings of the Annual Technical Conference-Society Of Vacuum Coaters, Lake Buena Vista, FL, USA, 13-18 April 2002; pp. 163-169.

50. Li, Z.; Ju, J.; Xu, W. Daylighting Control Performance and Subject Responses to Electrochromic Windows in a Meeting Room. Procedia Eng. 2015, 121, 27-32. [CrossRef]

51. Miyatake, M.; Akahori, H.; Yoshimoto, S. Deformation of large liquid crystal display glass sheets across a gap between noncontact transportation devices. Precis. Eng. 2016, 46, 360-368. [CrossRef]

52. Sbar, N.L.; Podbelski, L.; Yang, H.M.; Pease, B. Electrochromic dynamic windows for office buildings. Int. J. Sustain. Built Environ. 2012, 1, 125-139. [CrossRef]

53. Lee, S.E.; DiBartolomeo, D.L. Application issues for large-area electrochromic windows in commercial buildings. Sol. Energy Mater. Sol. Cells 2002, 71, 465-491. [CrossRef]

54. Chakrapani, S.; Slovak, S.M.; Saxe, R.L.; Fanning, B. SPD Films and Light Valves Comprising Same. U.S. Patent 6,416,827, 9 July 2002.

55. Barrios Puerto, D. Characterization and Applications of New Electrochromic Devices: Comparison with Other Electrically Controllable Transmittance Technologies; Universidad Carlos III de Madrid: Madrid, Spain, 2012.

56. Japan-Display LCD Basics. Available online: http://www.j-display.com/english/technology/lcdbasic.html (accessed on 20 June 2017).

57. Gauza, S.; Zhu, X.; Piecek, W.; Dabrowski, R.; Wu, S.T. Fast switching liquid crystals for color-sequential LCDs. J. Disp. Technol. 2007, 3, 250-252. [CrossRef]

58. DeForest, N.; Shehabi, A.; Selkowitz, S.; Milliron, D.J. A comparative energy analysis of three electrochromic glazing technologies in commercial and residential buildings. Appl. Energy 2017, 192, 95-109. [CrossRef]

59. Runnerstrom, E.L.; Llordés, A.; Lounis, S.D.; Milliron, D.J. Nanostructured electrochromic smart windows: Traditional materials and NIR-selective plasmonic nanocrystals. Chem. Commun. 2014, 50, 10555-10572. [CrossRef] [PubMed] 
60. Korgel, B.A. Materials science: Composite for smarter windows. Nature 2013, 500, 278-279. [CrossRef] [PubMed]

61. Ghosh, A.; Norton, B.; Duffy, A. Measured thermal performance of a combined suspended particle switchable device evacuated glazing. Appl. Energy 2016, 169, 469-480. [CrossRef]

62. Cho, N.H.; Nayek, P.; Lee, J.J.; Lim, Y.J.; Lee, J.H.; Lee, S.H.; Park, H.S.; Lee, H.J.; Kim, H.S. High-performance, in-plane switching liquid crystal device utilizing an optically isotropic liquid crystal blend of nanostructured liquid crystal droplets in a polymer matrix. Mater. Lett. 2015, 153, 136-139. [CrossRef]

63. Matsumoto, S.; Sugiyama, Y.; Sakata, S.; Hayashi, T. Electro-optic effect, propagation loss, and switching speed in polymers containing nano-sized droplets of liquid crystal. Liq. Cryst. 2000, 27, 649-655. [CrossRef]

64. Lizana, A.; Moreno, I.; Márquez, A.; Lemmi, C.; Campos, J.; Yzuel, M.J. Influence of the temporal fluctuations phenomena on the ECB LCoS performance. In Proceedings of the SPIE Optical Engineering+ Applications, San Diego, CA, USA, 2-6 August 2009; International Society for Optics and Photonics: San Diego, CA, USA, 2009; p. 74420G.

65. Granqvist, C.G. Electrochromic tungsten oxide films: Review of progress 1993-1998. Sol. Energy Mater. Sol. Cells 2000, 60, 201-262. [CrossRef]

66. Piccolo, A. Thermal performance of an electrochromic smart window tested in an environmental test cell. Energy Build. 2010, 42, 1409-1417. [CrossRef]

67. Block, M.; Bokalders, V. The Whole Building Handbook: How to Design Healthy, Efficient and Sustainable Buildings; Routledge: Abingdon, UK, 2010.

68. Jelle, B.P. Solar radiation glazing factors for window panes, glass structures and electrochromic windows in buildings-Measurement and calculation. Sol. Energy Mater. Sol. Cells 2013, 116, 291-323. [CrossRef]

69. Matthews, J.P.; Bell, J.M.; Skryabin, I.L. Simulation of electrochromic switching voltages at elevated temperatures. Electrochim. Acta 2001, 46, 1957-1961. [CrossRef]

70. Baldassarri, C.; Shehabi, A.; Asdrubali, F.; Masanet, E. Energy and emissions analysis of next generation electrochromic devices. Sol. Energy Mater. Sol. Cells 2016, 156, 170-181. [CrossRef]

71. Ghosh, A.; Norton, B.; Duffy, A. Measured overall heat transfer coefficient of a suspended particle device switchable glazing. Appl. Energy 2015, 159, 362-369. [CrossRef]

72. Ghosh, A.; Norton, B.; Duffy, A. Behaviour of a SPD switchable glazing in an outdoor test cell with heat removal under varying weather conditions. Appl. Energy 2016, 180, 695-706. [CrossRef]

73. Bloisi, F.; Vicari, L. Polymer-dispersed liquid crystals. In Optical Applications of Liquid Crystals; Taylor and Francis Group: Burlington, MA, USA, 2003; pp. 148-200.

74. Collaborative, E.W. Liquid Crystal Device Windows. Available online: http:/ /www.commercialwindows. org/liquidcrystal.php (accessed on 20 July 2017).

75. Papaefthimiou, S.; Leftheriotis, G.; Yianoulis, P. Advanced electrochromic devices based on WO 3 thin films. Electrochim. Acta 2001, 46, 2145-2150. [CrossRef]

76. Ghosh, A.; Norton, B.; Duffy, A. First outdoor characterisation of a PV powered suspended particle device switchable glazing. Sol. Energy Mater. Sol. Cells 2016, 157, 1-9. [CrossRef]

77. Yan, J.; Li, Y.; Wu, S.T. High-efficiency and fast-response tunable phase grating using a blue phase liquid crystal. Opt. Lett. 2011, 36, 1404-1406. [CrossRef] [PubMed]

78. Jung, D.; Choi, W.; Park, J.Y.; Kim, K.B.; Lee, N.; Seo, Y.; Kim, H.S.; Kong, N.K. Inorganic gel and liquid crystal based smart window using silica sol-gel process. Sol. Energy Mater. Sol. Cells 2017, 159, 488-495. [CrossRef]

79. Khaligh, H.H.; Liew, K.; Han, Y.; Abukhdeir, N.M.; Goldthorpe, I.A. Silver nanowire transparent electrodes for liquid crystal-based smart windows. Sol. Energy Mater. Sol. Cells 2015, 132, 337-341. [CrossRef]

80. Park, S.; Hong, J.W. Polymer dispersed liquid crystal film for variable-transparency glazing. Thin Solid Films 2009, 517, 3183-3186. [CrossRef]

81. Selkowitz, S.E.; Rubin, M.; Lee, E.S.; Sullivan, R. A Review of electrochromic window performance factors. In Optical Materials Technology for Energy Efficiency and Solar Energy Conversion XIII; International Society for Optics and Photonics: Freiburg, Germany, 1994; pp. 226-248.

82. Papaefthimiou, S.; Syrrakou, E.; Yianoulis, P. Energy performance assessment of an electrochromic window. Thin Solid Films 2006, 502, 257-264. [CrossRef] 
83. Cupelli, D.; Nicoletta, F.P.; Manfredi, S.; Vivacqua, M.; Formoso, P.; De Filpo, G.; Chidichimo, G. Self-adjusting smart windows based on polymer-dispersed liquid crystals. Sol. Energy Mater. Sol. Cells 2009, 93, 2008-2012. [CrossRef]

84. DeForest, N.; Shehabi, A.; Garcia, G.; Greenblatt, J.; Masanet, E.; Lee, E.S.; Selkowitz, S.; Milliron, D.J. Regional performance targets for transparent near-infrared switching electrochromic window glazings. Build. Environ. 2013, 61, 160-168. [CrossRef]

85. Lee, E. High Performance Building Facade Solutions; PIER Final Project Report; Lawrence Berkeley National Laboratory: Berkeley, CA, USA, 2011.

86. Selkowitz, S.; Lee, E. Field Testing of Dynamic Façade Controls in Highly Glazed Buildings for Energy Efficiency and Comfort; Glass Processing Days: Tampere, Finland, 2005; pp. 557-561.

87. Wigginton, M.; Harris, J. Intelligent Skins; Routledge: Oxford, UK, 2013.

88. Schaeffer, O.; Vogt, M.-M. Move: Architecture in Motion-Dynamic Components and Elements; Walter de Gruyter: Berlin, Germany, 2010.

89. Moloney, J. Designing Kinetics for Architectural Facades: State Change; Taylor \& Francis: Abingdon, UK, 2011.

90. Asefi, M. Transformable and Kinetic Architectural Structures: Design, Evaluation and Application to Intelligent Architecture; Dr. Müller: Liverpool, UK, 2010.

91. Orsi, A. An Exploration of the Impact of Fixed Shading Device Geometry on Building Energy Performance; ProQuest: Ann Arbor, MI, USA, 2009.

92. Laustsen, J.B.; Santos, I.D.; Svendsen, S.; Traberg-Borup, S.; Johnsen, K. Solar shading system based on daylight directing glass lamellas. In Proceedings of the NSB2008, 8th Symposium on Building Physics in the Nordic Countries: Symposium on Building Physics in the Nordic Countries, Copenhagen, Denmark, 16-18 June 2008; pp. 111-118.

93. Hammad, F.; Abu-Hijleh, B. The energy savings potential of using dynamic external louvers in an office building. Energy Build. 2010, 42, 1888-1895. [CrossRef]

94. Baldinelli, G. Double skin facades for warm climate regions: Analysis of a solution with an integrated movable shading system. Build. Environ. 2009, 44, 1107-1118. [CrossRef]

95. Kensek, K.; Hansanuwat, R. Environment control systems for sustainable design: A methodology for testing, simulating and comparing kinetic facade systems. J. Creat. Sustain. Archit. Built Environ. 2011, 1, $27-46$.

96. COLT Group. Glass Rotating Shading System. Available online: http://www.coltgroup.com/europeancommission-headquarters.html (accessed on 13 June 2017).

97. COLT Group. Solar Shading System. Available online: http://www.colt.es/tl_files/pdf/Solar\%20Shading/ Maximising\%20energy\%20performance\%20and\%20productivity\%20with\%20solar\%20shading.pdf (accessed on 20 June 2017).

98. COLT Group. Metal Rotating Shading Device. Available online: http://www.coltgroup.com/zurich-airport. html (accessed on 13 June 2017).

99. COLT Group. Maximizing Energy Performance and Productivity with Solar Shading. Available online: $\quad$ file:// /C:/Users/D_Q.com/Downloads/Maximising\%20energy\%20performance\%20and\% 20productivity\%20with\%20solar\%20shading.pdf (accessed on 4 August 2017).

100. COLT Group. Solar Shading Louver System. Available online: https://www.coltinfo.co.uk/files/pdf/UK/ Shadoglass\%20and\%20Shadovoltaic\%20solar\%20shading\%20systems.pdf (accessed on 20 June 2017).

101. Kuribayashi, K.; Tsuchiya, K.; You, Z.; Tomus, D.; Umemoto, M.; Ito, T.; Sasaki, M. Self-deployable origami stent grafts as a biomedical application of Ni-rich TiNi shape memory alloy foil. Mater. Sci. Eng. A 2006, 419, 131-137. [CrossRef]

102. Nishiyama, Y. Miura folding: Applying origami to space exploration. Int. J. Pure Appl. Math. 2012, 79, 269-279.

103. Addington, D.M.; Schodek, D.L. Smart Materials and New Technologies: For the Architecture and Design Professions; Routledge: Oxford, UK, 2005.

104. Otsuka, K.; Wayman, C. Mechanism of Shape Memory Effect and Superelasticity. Shape Memory Materials. 1998, pp. 27-49. Available online: https://books.google.com.hk/books?hl=zh-CN\&lr=\&id= DvItE9XU1N8C\&oi=fnd\&pg=PR11\&dq=In+Shape+Memory+Materials\%3B+1998\&ots=xk91Cbje_P\&sig= xw3rvHHQcJI7CdLilMrLyPCQ4ks\&redir_esc=y\#v=onepage\&q=In\%20Shape \%20Memory\%20Materials\% 3B\%201998\&f=false (accessed on 20 September 2017). 
105. Trolier-McKinstry, S.; Newnham, R. Sensors, actuators, and smart materials. MRS Bull. 1993, 18, $27-33$. [CrossRef]

106. Fiorito, F.; Sauchelli, M.; Arroyo, D.; Pesenti, M.; Imperadori, M.; Masera, G.; Ranzi, G. Shape morphing solar shadings: A review. Renew. Sustain. Energy Rev. 2016, 55, 863-884. [CrossRef]

107. Sun, L.; Huang, W.M.; Ding, Z.; Zhao, Y.; Wang, C.C.; Purnawali, H.; Tang, C. Stimulus-responsive shape memory materials: A review. Mater. Des. 2012, 33, 577-640. [CrossRef]

108. Otsuka, K.; Wayman, C.M. Shape Memory Materials; Cambridge University Press: Cambridge, UK, 1999.

109. Lienhard, J.; Schleicher, S.; Poppinga, S.; Masselter, T.; Milwich, M.; Speck, T.; Knippers, J. Flectofin: A hingeless flapping mechanism inspired by nature. Bioinspir. Biomim. 2011, 6, 045001. [CrossRef] [PubMed]

110. Suralkar, R. Solar Responsive Kinetic Facade Shading Systems inspired by plant movements in nature. In Proceedings of the Conference: People and Buildings held at the offices of Arup UK, London, UK, 23 September 2011.

111. Archdaily One Ocean, Thematic Pavilion EXPO 2012/Soma. Available online: http:/ /www.archdaily.com/ 236979/one-ocean-thematic-pavilion-expo-2012-soma (accessed on 29 August 2016).

112. Payne, A.O.; Johnson, J.K. Firefly: Interactive prototypes for architectural design. Archit. Des. 2013, 83, 144-147. [CrossRef]

113. Lignarolo, L.; Lelieveld, C.; Teuffel, P. Shape morphing wind-responsive facade systems realized with smart materials. In Proceedings of the International Adaptive Architecture Conference, London, UK, 3-5 March 2011; pp. 3-5.

114. Kretzer, M.; Rossi, D. ShapeShift. Leonardo 2012, 45, 480-481. [CrossRef]

115. Karamata, B.; Andersen, M. Concept, Design and Performance of a Shape Variable Mashrabiya as a Shading and Daylighting System for Arid Climates. In Proceedings of the 30th PLEA Conference-Sustainable Habitat for Developing Societies, Ahmedabad, India, 16-18 December 2014; pp. 344-351.

116. Yoo, S.H.; Lee, E.T.; Lee, J. Building integrated photovoltaics: A Korean case study. Sol. Energy 1998, 64, 151-161. [CrossRef]

117. Yoo, S.H.; Lee, E.T. Efficiency characteristic of building integrated photovoltaics as a shading device. Build. Environ. 2002, 37, 615-623. [CrossRef]

118. Yoo, S.-H.; Manz, H. Available remodeling simulation for a BIPV as a shading device. Sol. Energy Mater. Sol. Cells 2011, 95, 394-397. [CrossRef]

119. Alonso, J.; Diaz, V.; Hernandez, M.; Bercero, F.; Canizo, C.; Pou, I.; Mohedano, R.; Benitez, P.; Minano, J.C.; Luque, A. A new static concentrator PV module with bifacial cells for integration on facades: The PV VENETIAN store. In Proceedings of the Photovoltaic Specialists Conference, New Orleans, LA, USA, 19-24 May 2002; pp. 1584-1587.

120. ElSayed, M.S. Optimizing thermal performance of building-integrated photovoltaics for upgrading informal urbanization. Energy Build. 2016, 116, 232-248. [CrossRef]

121. Khedari, J.; Waewsak, J.; Supheng, W.; Hirunlabh, J. Experimental investigation of performance of a multi-purpose PV-slat window. Sol. Energy Mater. Sol. Cells 2004, 82, 431-445. [CrossRef]

122. Priatman, J.; Soegihardjo, O.; Loekita, S. Towards Energy Efficient Facade Through Solar-powered Shading Device. Procedia Soc. Behav. Sci. 2015, 179, 266-275. [CrossRef]

123. Kim, S.H.; Kim, I.T.; Choi, A.S.; Sung, M. Evaluation of optimized PV power generation and electrical lighting energy savings from the PV blind-integrated daylight responsive dimming system using LED lighting. Sol. Energy 2014, 107, 746-757. [CrossRef]

124. Saranti, A.; Tsoutsos, T.; Mandalaki, M. Sustainable Energy Planning. Design Shading Devices with Integrated Photovoltaic Systems for Residential Housing Units. Procedia Eng. 2015, 123, 479-487. [CrossRef]

125. Stamatakis, A.; Mandalaki, M.; Tsoutsos, T. Multi-criteria analysis for PV integrated in shading devices for Mediterranean region. Energy Build. 2016, 117, 128-137. [CrossRef]

126. Mandalaki, M.; Tsoutsos, T.; Papamanolis, N. Integrated PV in shading systems for Mediterranean countries: Balance between energy production and visual comfort. Energy Build. 2014, 77, 445-456. [CrossRef]

127. Furundzic, A.K.; Kosoric, V.; Golic, K. Potential for reduction of $\mathrm{CO}_{2}$ emissions by integration of solar water heating systems on student dormitories through building refurbishment. Sustain. Cities Soc. 2012, 2, 50-62. [CrossRef]

128. Probst, M.M.; Roecker, C. Towards an improved architectural quality of building integrated solar thermal systems (BIST). Sol. Energy 2007, 81, 1104-1116. [CrossRef] 
129. Zhai, X.Q.; Wang, R.Z.; Dai, Y.J.; Wu, J.Y.; Ma, Q. Experience on integration of solar thermal technologies with green buildings. Renew. Energy 2008, 33, 1904-1910. [CrossRef]

130. Motte, F.; Notton, G.; Cristofari, C.; Canaletti, J.L. Design and modelling of a new patented thermal solar collector with high building integration. Appl. Energy 2013, 102, 631-639. [CrossRef]

131. Abu-Zour, A.M.; Riffat, S.B.; Gillott, M. New design of solar collector integrated into solar louvres for efficient heat transfer. Appl. Therm. Eng. 2006, 26, 1876-1882. [CrossRef]

132. Palmero-Marrero, A.I.; Oliveira, A.C. Evaluation of a solar thermal system using building louvre shading devices. Sol. Energy 2006, 80, 545-554. [CrossRef]

133. Chou, D.C.; Chang, C.S.; Chang, J.C. Energy conservation using solar collectors integrated with building louver shading devices. Appl. Therm. Eng. 2016, 93, 1282-1294. [CrossRef]

134. Saadatian, O.; Sopian, K.; Mat, S.B.; Elhab, B.; Lim, C.; Ruslan, M. Solar Collectors as Shading Devices for Kuala Lumpur, Malaysia. 2013. Available online: http:/ /www.wseas.us/e-library/conferences/2012/Zlin/ ENAGROBIO/ENAGROBIO-13.pdf (accessed on 20 September 2017).

135. Maroy, K.; Carbonez, K.; Steeman, M.; Van Den Bossche, N. Assessing the thermal performance of insulating glass units with infrared thermography: Potential and limitations. Energy Build. 2017, 138, 175-192. [CrossRef]

136. COLT Group. Solar-Leaf Bioreactor Façade. Available online: http://www.coltinfo.co.uk/files/pdf/UK/ SolarLeaf\%20bioreactor\%20facade.pdf (accessed on 23 June 2017).

137. Kim, H.K. Climate change: Sustainability performance of a Bio-facade for a retrofitted building. In Proceedings of the ARCC Conference Repository, University of North Carolina at Charlotte, Charlotte, NC, USA, 12-15 February 2014.

138. Van Den Wymelenberg, K. Patterns of occupant interaction with window blinds: A literature review. Energy Build. 2012, 51, 165-176. [CrossRef]

139. Frontczak, M.; Andersen, R.V.; Wargocki, P. Questionnaire survey on factors influencing comfort with indoor environmental quality in Danish housing. Build. Environ. 2012, 50, 56-64. [CrossRef]

140. Inoue, T.; Kawase, T.; Ibamoto, T.; Takakusa, S.; Matsuo, Y. The development of an optimal control system for window shading devices based on investigations in office buildings. ASHRAE Trans. 1988, 94, 1034-1049.

141. Sutter, Y.; Dumortier, D.; Fontoynont, M. The use of shading systems in VDU task offices: A pilot study. Energy Build. 2006, 38, 780-789. [CrossRef]

142. Galasiu, A.D.; Veitch, J.A. Occupant preferences and satisfaction with the luminous environment and control systems in daylit offices: A literature review. Energy Build. 2006, 38, 728-742. [CrossRef]

143. Reinhart, C.F.; Voss, K. Monitoring manual control of electric lighting and blinds. Light. Res. Technol. 2003, 35, 243-258. [CrossRef]

144. Wienold, J. Dynamic simulation of blind control strategies for visual comfort and energy balance analysis. Build. Simul. 2007, 1197-1204.

145. Bakker, L.G.; Hoes-van Oeffelen, E.C.M.; Loonen, R.C.G.M.; Hensen, J.L.M. User satisfaction and interaction with automated dynamic facades: A pilot study. Build. Environ. 2014, 78, 44-52. [CrossRef]

146. Colaco, S.G.; Kurian, C.P.; George, V.I.; Colaco, A.M. Prospective techniques of effective daylight harvesting in commercial buildings by employing window glazing, dynamic shading devices and dimming control-A literature review. Build. Simul. 2008, 1, 279-289. [CrossRef]

147. Escuyer, S.; Fontoynont, M. Lighting controls: A field study of office workers' reactions. Light. Res. Technol. 2001, 33, 77-94. [CrossRef]

148. Mahdavi, A.; Mohammadi, A.; Kabir, E.; Lambeva, L. Occupants' operation of lighting and shading systems in office buildings. J. Build. Perform. Simul. 2008, 1, 57-65. [CrossRef]

149. Skelly, M.; Wilkinson, M. The evolution of interactive facades: Improving automated blind control. Whole Life Perform. Facades 2001, 129-142.

150. Vine, E.; Lee, E.; Clear, R.; DiBartolomeo, D.; Selkowitz, S. Office worker response to an automated venetian blind and electric lighting system: A pilot study. Energy Build. 1998, 28, 205-218. [CrossRef]

151. Konstantoglou, M.; Tsangrassoulis, A. Dynamic building envelope system: A control strategy for enhancing daylighting quality and reducing energy consumption. In Proceedings of the Energy Forum Conference, Dubai, UAE, 22-24 October 2012; pp. 6-7.

152. Tzempelikos, A.; Athienitis, A.K. The impact of shading design and control on building cooling and lighting demand. Sol. Energy 2007, 81, 369-382. [CrossRef] 
153. Papamichael, K.M.; Rubinstein, F.; Selkowitz, S.; Ward, G. The Integration of Operable Shading Systems and Electric Lighting Controls; Windows and Lighting Program; Lawrence Berkeley Laboratory: Berkeley, CA, USA, 1986.

154. Bauer, M.; Geiginger, J.; Hegetschweiler, W.; Morel, N.; Sejkora, G.; Wurmsdobler, P. Delta: A Blind Controller Using Fuzzy Logic. 1996. Available online: https://infoscience.epfl.ch/record/121517 (accessed on 20 September 2017).

155. Zawidzki, M. Dynamic shading of a building envelope based on rotating polarized film system controlled by one-dimensional cellular automata in regular tessellations (triangular, square and hexagonal). Adv. Eng. Inform. 2015, 29, 87-100. [CrossRef]

156. Wei, Z.; Yiqun, W.; Menghui, S. Modeling and simulation of electric-hydraulic control system for bending roll system, Robotics, Automation and Mechatronics. In Proceedings of the 2008 IEEE Conference on Robotics, Automation and Mechatronics, Chengdu, China, 21-24 September 2008; pp. 661-664.

157. COLT Group. Architectural Solutions, Solar Shading Systems. Available online: http://erra.com.tr/medya/ gunes/solar-shading-systems.pdf (accessed on 23 June 2017).

158. Gage, S.A.; Thorne, W. Edge monkeys-the design of habitat specific robots in buildings. Technoetic Arts 2005, 3, 169-179. [CrossRef]

159. Tracy, C.E.; Zhang, J.G.; Benson, D.K.; Czanderna, A.W.; Deb, S.K. Accelerated durability testing of electrochromic windows. Electrochim. Acta 1999, 44, 3195-3202. [CrossRef]

160. Lampert, C.M.; Agrawal, A.; Baertlien, C.; Nagai, J. Durability evaluation of electrochromic devices-an industry perspective. Sol. Energy Mater. Sol. Cells 1999, 56, 449-463. [CrossRef]

161. Piccolo, A.; Simone, F. Performance requirements for electrochromic smart window. J. Build. Eng. 2015, 3, 94-103. [CrossRef]

162. Pesenti, M.; Masera, G.; Fiorito, F. Shaping an Origami shading device through visual and thermal simulations. Energy Procedia 2015, 78, 346-351. [CrossRef]

163. Jelle, B.P.; Breivik, C.; Røkenes, H.D. Building integrated photovoltaic products: A state-of-the-art review and future research opportunities. Sol. Energy Mater. Sol. Cells 2012, 100, 69-96. [CrossRef]

164. Hay, M. Hamburg Now Has an Algae Powered Building. Available online: https://www.good.is/articles/ algae-powered-building (accessed on 22 June 2017).

165. Wallis, D. When Algae on the Exterior Is a Good Thing. Available online: http://www.nytimes.com/2013/ 04/25/business / energy-environment/german-building-uses-algae-for-heating-and-cooling.html?_r=0 (accessed on 24 June 2017). 